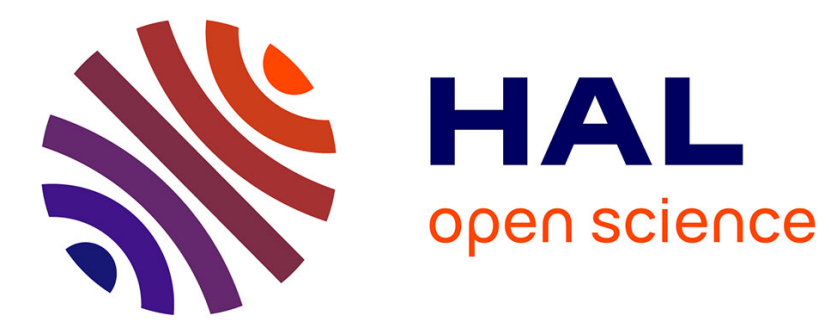

\title{
State provision of constitutional goods
}

Romain Espinosa

\section{To cite this version:}

Romain Espinosa. State provision of constitutional goods. Constitutional Political Economy, 2016, 27 (1), pp.1-40. 10.1007/s10602-015-9198-y . halshs-01634210

\section{HAL Id: halshs-01634210 https://shs.hal.science/halshs-01634210}

Submitted on 14 Nov 2017

HAL is a multi-disciplinary open access archive for the deposit and dissemination of scientific research documents, whether they are published or not. The documents may come from teaching and research institutions in France or abroad, or from public or private research centers.
L'archive ouverte pluridisciplinaire $\mathbf{H A L}$, est destinée au dépôt et à la diffusion de documents scientifiques de niveau recherche, publiés ou non, émanant des établissements d'enseignement et de recherche français ou étrangers, des laboratoires publics ou privés. 


\title{
State Provision of Constitutional Goods
}

\author{
Romain Espinosa*
}

June 16, 2015

\begin{abstract}
This paper investigates the impact of constitutional rights on the level of public expenditure in a large sample of countries. To do so, we construct a panel of 73 countries from 1960 to 2011. We first investigate factors that drive constitutional changes regarding constitutional rights. To address potential endogeneity concerns in the choice of constitutional rules, we rely on an instrumental variable within estimation (country and time fixed effects) to estimate the impact of constitutional rights on government size. We find that larger governments tend to inscribe fewer rights in their constitutions, but we do not detect any impact of constitutional rights on the government size.
\end{abstract}

JEL: $\quad$ E60, H50, K10

Keywords: constitutional rights, constitutional economics, government expenditure, government size, endogenous constitutions.

* Romain Espinosa, CRED (TEPP), University of Paris II Panthéon-Assas, 12 Place du Panthéon, 75005 Paris, France. E-mail: romain.espinosa@u-paris2.fr, tel: +33 (0)1 444156 60, fax: + 33 (0)1 44078320 .

Acknowledgments I wish to thank Stefan Voigt, Tom Ginsburg, Jerg Gutmann, Bruno Deffains, and two anonymous referees for their very helpful comments on earlier drafts of this paper. I am also indebted to Régis Blazy for his very detailed remarks at the ACDD days in Strasbourg. 


\section{Introduction}

Recent developments in the Constitutional Political Economy literature have studied the relationship between constitutional rules and state behavior. These works aimed to assess the impact of constitutional provisions on economic outcomes. So far, two sets of constitutional rules have received most of the attention, i.e., rules defining de jure judicial independence (Feld and Voigt (2003), Hayo and Voigt (2007), Hayo and Voigt (2013), Melton and Ginsburg (2014), Holcombe and Rodet (2012)), and electoral/governmental rules (Persson and Tabellini (2004), Persson and Tabellini (2005), Blume et al. (2009)).

Strikingly, the impact of constitutional rights on public expenditure has not been discussed. Constitutional rights have more than once been the subject of close theoretical scrutiny (Sugden (1993)). For instance, Bose (2010) highlighted the central role that constitutional rights play in the institutional game. Elkins et al. (2013) have documented the rise of constitutional rights since the end of WWII. Law and Versteeg (2013) have investigated the relationship between constitutional rights and human rights violations.

Our work builds on these previous lines of research and proposes to investigate the economic impact of constitutional rights on state expenditure. To do so, we rely on previous discussions introduced by Voigt (2011), who considers constitutions to be public goods. Similarly, we propose to address constitutional rights as goods the state is required to provide. Indeed, constitutional rights are, by their very nature, substantive provisions that constitution-makers ask the state to respect and/or to implement. Because constitutional rights are, as a matter of principle, publicly provided, more inclusive constitutions are expected to induce larger governments. To put it bluntly: the more constitutional goods are inscribed in a constitution, the more the state will have to intervene in the economy. Our paper aims to test this last implication.

To answer this research question, we need to address some empirical challenges. First, we need to construct an index, which accounts for the number of rights inscribed in each country's constitution. To do so, we use the data introduced by Elkins et al. (2013). Second, to address the unobserved heterogeneity of our data, we are forced to consider fixed effects models, which limits our analysis to countries that have effectively changed their number of constitutional rights since 1960. Because sample selection might result from such restrictions, we determine which countries were the most likely to incur constitutional changes. We then investigate which factors influenced the determination of the number of rights inscribed in a constitution. Finally, we use IV-techniques to estimate the causal effect of the number of constitutional rights on the size of government.

The paper is organized as follows. We first discuss how constitutional rights can be expected to induce larger governments (Section 2). Second, we introduce the data and show some stylized facts (Section 3). Then, we discuss which countries were likely to change their number of rights since 1960 and which factors affected their choice when they selected the constitutional rights. Because of the potential endogeneity concerns we detect, we rely on an instrumental variable approach to estimate the causal impact of constitutional rights on government size (Section 4). Finally, we summarize our results and put them in perspective with the existing literature (Section 5).

\section{The Relationship between Constitutional Rights and the Size of Government}

Constitutional rights have received a significant attention by both public actors and legal scholars since WWII. The UN declaration of Human Rights (Elkins et al. (2013)), together with the two international covenants on human rights and the subsequent international treaties, have led to a 
worldwide recognition, at least virtually, of individual and social rights. ${ }^{1}$ As a consequence, human rights have become increasingly integrated into national constitutions and therefore have been given an internal legal value in numerous legal systems.

The question of enforcing constitutional rights, however, has become more complex. On the one side, it has been argued that constitutional rights may improve human rights only if states are willing to enforce them. In this view, constitutional rights mainly pursue an expressive purpose. For instance, states that inscribe rights in their constitution may lack the financial resources to enforce them (Bjørnskov and Mchangama (2013)). On the other side, the growing expansion of judicial review that took place with the succeeding waves of democratization (Ginsburg and Versteeg (2013)) has reinforced the legal scope of constitutional rights. Constitutional courts have developed a comprehensive set of mechanisms to make constitutional promises real.

The mechanisms used by courts to enforce constitutional rights are very diverse, and few courts adopt trans-substantive approaches. ${ }^{2}$ Enforcement techniques, and thus enforcement consequences, are likely to vary with the nature of the right at stake. However, all rights, to one point or another, are likely to call for more state intervention. The extent to which the state is required to intervene depends on both the nature of the right and the enforcement mechanism of the national courts.

\subsection{Constitutional Rights Calling for Larger Governments}

Several categorizations have been proposed to discuss constitutional rights, including political versus social rights, individual versus group rights, and positive versus negative rights. We use the latter - and the most popular - categorization to discuss how constitutional rights may call for greater state intervention and, therefore, may induce larger governments.

The classical dichotomy between positive and negative rights focuses on their substantive implication for the relationship between citizens and the state. In Justice Barak's view, "negative rights define the limitations on a constitutional right that the state is precluded from imposing". On the other hand, he explains positive rights as those that "define the actions that the state is obligated to take in order to protect a constitutional right" (Barak (2012), p. 742). Prima facie, a restrictive approach would conclude that only positive rights lead to an increase in public expenditure. One can argue, however, that both types of rights are likely to increase the size of government.

Positive Rights Standard examples of positive rights include the right to housing, the right to employment, and the right to health care. Regarding the latter, one expects the state to intervene in the economy to ensure that citizens have effective access to health care. In some cases, it imposes on the state a duty of health care provision for those who would be excluded from the private health care system, mainly because of financial constraints. It is then obvious that, if positive constitutional rights are indeed enforced by the state, they increase the burden of the government and, therefore, increase the size of the government.

A useful illustration of positive rights can be found in the jurisprudence of the Indian Supreme Court. In addition to individual rights, the Indian constitution provides a list of social-economic

\footnotetext{
${ }^{1}$ Although many countries have ratified the International Covenant on Economic, Social, and Cultural Rights (ICESCR), only a few of them have actually ratified the UN protocol aimed at enforcing the Economic, Social, and Cultural Rights. States seem to agree on which rights should be promoted, but some of them are reluctant to ensure their justiciability at the national level.

${ }^{2} \mathrm{~A}$ trans-substantive approach considers that all constitutional rights necessitate the same degree of scrutiny, whatever the nature of the right at stake. The alternative consists of taking different interpretative approaches for different rights. For instance, racial discrimination and sex discrimination receive different levels of scrutiny in the United States (respectively, strong and medium).
} 
rights known as the Directive Principles. These social rights were originally meant to be purely declarative because the Constitution explicitly excludes them from judicial review. Nevertheless, the Indian Supreme Court has integrated them over time into the realm of judicial review by arguing that they were inherent to the concept of human dignity (which is included in the individual rights section). Several decisions have compelled the state to more intervene in more issues and, therefore to increase its expenditure. In Bandhua Mukti Morcha v. Union of India, the Supreme Court of India decided that the state was responsible for the infringement of constitutional rights in so far as it did not undertake measures to monitor the enforcement of the legislation by private parties (in this instance, the right to work in decent conditions). In Daily Rated Casual Labour [...] v. Union of India, the Supreme Court of India decided that "[t]he Government should be a model employer" and that it could not "compel any worker to work even as a casual labourer on starving wages". In its decision, the Court relied on the Directive Principles (Article 38(2)), which require the state to seek to minimize inequalities in the society. The aforementioned decisions best illustrate how positive rights may induce larger governments.

Negative Rights Contrary to positive rights, assessing the impact of negative rights on state expenditure is a more complex task. Negative rights indeed aim at reducing the intervention of the state in areas where its intervention could harm individual liberties. In proportionality terms, the violation of these rights is so costly that no social benefits could outweigh the social costs of their limitation. Rights contained in the first ten Amendments of the US Constitution usually fall into this category. These rights, however, do not necessarily preclude the state from any intervention. As is the case in a proportionality framework, the state remains under the obligation to enact any alternative measure that would be less intrusive. ${ }^{3}$ This, in turn, implies that states are forced to rely on more costly policies when these allow for achieving similar objectives while being less intrusive.

A good illustration of this reasoning can be found in United States $v$. Jones. In this case, the US Supreme Court was asked to decide on the constitutional validity of evidence obtained by the police through the use of GPS tracking devices. Justice Scalia, delivering the opinion of the Court, concluded that attaching a GPS tracking device to a suspect's vehicle was unconstitutional because it violated the Fourth Amendment. Reacting to the concurring opinion of Justice Alito, Justice Scalia recognized that the Fourth Amendment would not have been violated if the police had followed the suspect on the street instead of attaching a device to his vehicle. In his words: "Thus, even assuming that the concurrence is correct to say that traditional surveillance of Jones for a 4-week period would have required a large team of agents, multiple vehicles, and perhaps aerial assistance our cases suggest that such visual observation is constitutionally permissible". In other words, the Fourth Amendment, by imposing limitations on the state, forces public authorities to take more costly measures to achieve equivalent social objectives.

\subsection{Factors Mitigating the Impact of Constitutional Rights}

Despite the above arguments, some factors can mitigate the impact of constitutional rights on government size.

Rights as Signals First, constitutional rights might lead to larger governments only if governments are willing to fulfill their constitutional duties when legislating. This is especially the case

\footnotetext{
${ }^{3}$ Proportionality inquiries in constitutional law seek, among other things, to figure out whether the government's actions are the least right-infringing measures that effectively achieve the pursued social goal. If courts conclude that other measures would have somehow reached a similar objective and would have been less intrusive, they are very likely to strike down the government's decision.
} 
in autocratic countries, where leaders' preferences take precedence over constitutional provisions (Posner and Young (2007)). ${ }^{4}$ Several concerns emerge and raise questions regarding the government's willingness to enforce constitutional rights. Constitutional rights might serve as signals for some countries: rights might embody goals they aspire to reach but that they are unable to enforce; others, such as autocratic regimes, may only seek to mitigate the international pressure regarding domestic human rights violations or as part of an effort to receive international investments.

Enforcement by Courts To force governments to undertake measures to fulfill their constitutional duties, constitutions have been increasingly likely to empower constitutional courts. However, the great diversity of judicial review has led to very heterogeneous situations: some courts have developed strong mechanisms to coerce governments to undertake measures, while others clearly lack the independence or the judicial power to oppose the governments' decisions. Controlling for judicial review, however, is a difficult exercise because the scope and power of judicial review is often defined by courts themselves through case law. ${ }^{5}$ At the present time, no dataset is available to control for the de facto level of enforcement of constitutional rights. Estimating the impact of constitutional rights would therefore lead to an average effect, estimated at the average situation of constitutional enforcement.

Provision By Third Parties Some states delegate the provision of public goods to private companies. In such cases, even fully enforced constitutional rights might not affect the size of the government. It is true that, compared to a counterfactual state, which would provide public goods by itself, an outsourcing state would be less affected by constitutional rights. Other mechanisms, however, have been developed by the judiciary to bind private parties, which provide public goods to enforce constitutional rights. A useful illustration can be found in the Kadaan vs. Katzir case, decided by the Israeli Supreme Court. An Arab family that was willing to settle in a Jewish neighborhood called Katzir was denied authorization to move into the neighborhood by the Jewish Agency. This agency was partly delegated the authority of land allocation in the country by the state of Israel. The agency was intentionally discriminating against Arab families to promote Jewish culture in Israel. The Court ruled that, even though the agency was not a governmental agency, the very fact that the agency had been delegated this authority by the state made it subject to the same constitutional constraints as the state itself.

Similar mechanisms can be found in other countries. They aim to bind private or semi-public parties to enforce constitutional rights. Naturally, the introduction of new constitutional duties will have a stronger impact in insourcing states. However, mechanisms constraining delegated authorities are also likely to increase public expenditures: the state is ultimately responsible for the well-functioning provision of public goods, and may be asked to invest more or to intervene more to ensure that constitutional rights are effectively enforced. In this regard, a state with a given outsourcing level is also expected to incur a growth in public expenditure after the inscription of new rights in the constitution. However, we expect this increase to be lower than that for insourcing states because part of the cost is directly transferred to the citizens. Ultimately, the impact of constitutional rights on the government expenditure will depend on the allocation of

\footnotetext{
${ }^{4}$ Posner and Young (2007) ) investigate violations of constitutional provisions by African leaders. They state the following: "These cases remind us that many African leaders still possess the power to shape outcomes to suit their preferences, even when those preferences conflict with formal limitations on what they are legally permitted to do." (p. 134)

${ }^{5}$ The U.S. Supreme Court defined its scope of intervention in Marbury v. Madison. In India, the Supreme Court proclaimed that it was competent to assess the constitutionality of constitutional amendments in Minerva Mills $v$. Union of India.
} 
costs decided by the government. The state might decide either to partially fund the provision of a right by private parties or to leave it to the market. In any case, the level of public expenditure is very likely to increase when the state inscribes a right in its constitution. ${ }^{6}$

Legal Scope Constitutional rights may have a conditional impact depending on the legal scope courts give them. The two concepts of verticality and horizontality define the scope of the enforcement of constitutional rights. A right is said to have a vertical effect if the state is forced to enforce it when enforcing its own legislation. On the other side, horizontality refers to situations where courts recognize that a constitutional right also affects inter-citizen relationships. Vertical enforcement of constitutional rights is recognized in all countries with substantive judicial review because the very nature of constitutional review is to ensure that rights are well enforced by the state. On the contrary, horizontality has been recognized in fewer states because constitutions have mainly been seen as documents regulating the relationship between the state and its citizens. It is obvious, then, to see how vertical enforcement of constitutional rights is likely to induce larger governments: they ask for a direct intervention of the state for both positive and negative rights. The effect of horizontality, however, is less obvious. States with horizontal enforcement of constitutional rights might have larger governments because some understandings of horizontality require the state to take measures to ensure that constitutional rights are respected in inter-citizen relationships. An example is given by the German Constitutional Court, which recognized an indirect effect of horizontal enforcement (Drittwirkung), i.e., the state's duties to undertake measures to ensure horizontal enforcement of constitutional rights. Similar to the enforcement possibilities available to constitutional courts, no data have been collected to account for the legal scope given to constitutional rights by courts. Measuring the impact of constitutional rights on the size of government would therefore lead to an average effect. The estimated effect would be lower than the full effect in the case of complete horizontality, and greater than the effect in the case where horizontality is not recognized.

To put it in a nutshell, constitutional rights are expected to have a positive impact on the size of government. The great diversity of legal mechanisms available to judicial review, together with the very structure of each economy, implies that looking at the effect of constitutional rights without considering the specific institutional arrangement of each country can only yield an average effect estimation. Note, however, that estimates are robust to other institutional factors, such as federalism, to the extent that they do not vary over the period considered or that they are not correlated with the number of constitutional rights.

\section{$3 \quad$ Data and Stylized Facts}

The above discussion about the economic impact of constitutional rights concludes that constitutional rights induce larger governments. To assess the empirical validity of this claim, we build a panel dataset, which contains information about both government size and constitutional rights.

\subsection{Presentation of the dataset}

The above discussion about the economic impact of constitutional rights concludes that constitutional rights induce larger governments. In order to assess the empirical validity of this claim, we

\footnotetext{
${ }^{6}$ Bjørnskov and Mchangama (2013) write: "Whether the government produces or merely finances the access to, e.g., free education and health care services and provides substantial social security, [...], government expenditures are likely to be permanently larger if no other expenditures are cut." (p. 10)
} 
build a panel dataset, which contains information about both government size and constitutional rights.

Government Size First, as far as the government size is concerned, we compute the share of the government expenditure in GDP as the share of government consumption of the total GDP. We derive these data from the national accounts of the Penn World Table (PWT, Feenstra et al. (2013)), which covers countries from 1960 to 2011. In addition to these data, we also consider World Bank (WB) data about government consumption in GDP. Although the WB data are more limited, we use them as robustness checks to ensure that our results are not driven by specific features of the PWT data. We thus obtain two variables accounting for the size of government: $S I Z E^{P W T}$ and $S I Z E^{W B}$.

Rights Second, concerning the number of constitutional rights, we take over the variable constructed by Elkins et al. (2013). In their article, the authors introduce a unique worldwide dataset, which covers 74 constitutional rights. Following their work, we construct a variable RIGHTS, which is equal to the sum of rights written in a constitution (each right counts for 1 if it is mentioned in the constitution). By doing so, we obtain a variable that varies both across time and across countries. ${ }^{7}$

Determinants of Government Size The literature on the size of government has investigated some theories hypothesizing a causal effect of social, economic, and political variables on the level of public expenditure. Bergh and Karlsson (2010) investigated the relationship between government size and economic growth. Their investigation relies on Bayesian Averaging of Classical Estimates (BACE) and finds no relationship between the two variables. Benarroch and Pandey (2008) focus on the potential impact of trade openness on government size. Using a panel dataset from 1979 to 2000, they conclude that trade openness does not impact government size, unlike in the original study of Rodrik (1998). Alesina and Wacziarg (1998) explore both the relationship between country size and trade openness, on the one side, and government size, on the other. They find that governments tend to be relatively smaller in larger countries and that smaller countries tend to be more open to international trade. In a more recent study, Ram (2009) uses a very broad dataset to investigate the same research question. The paper relies on a fixed effects approach and concludes that there is a positive relationship between government size and both trade openness and country size. Furthermore, in a very detailed investigation, Shelton (2007) explores several theories that aim to explain government size. The paper takes into consideration the trade-off between integrating more variables into the estimation equation and the scarcity of the data, which usually leads to reduced samples. The author concludes that government size is (i) positively associated with trade openness, (ii) positively associated with the share of population over 65, (iii) negatively correlated with majoritarian electoral systems, (iv) not related to income, and (v) positively related to political rights. Finally, Holcombe and Rodet (2012) show that the rule of law is positively correlated with the size of government. All of these papers use static models and, if possible, integrate fixed effects in their estimations.

Constitutions and Government Size Following previous works on constitutional rules (Persson and Tabellini (2004), Persson and Tabellini (2005), Blume et al. (2009)), our investigation of the relationship between constitutional rights and the size of government takes into consideration several

\footnotetext{
${ }^{7}$ To assess the validity of this aggregate indicator, we computed the Cronbach's alpha for the indicator in 2012. We obtained a score of 0.926 , which indicates a very good internal consistency.
} 
dimensions. First, we control for some demographic and economic factors: the logarithm of the real GDP per capita $(L G D P)$, the logarithm of the population $(L P O P)$, the openness of the country $(O P E N)$, the share of the population below 14 years of age (POP14), and the share of the population above 65 years of age $(P O P 65) .{ }^{8}$ Second, we take into account some political factors: the level of de facto democracy $(P O L)$, a variable that accounts for the membership to the International Covenant on Civil and Political Rights (ICCPR), and the number of years the current constitution has been in force $(D U R) .^{9}$

\subsection{Frequency of Constitutional Changes and Rights Variations Since 1960}

Figure 1 displays both the number of new constitutions and the number of constitutional amendments per year since 1950. As we can see, the number of new constitutions varies from 1 to 20 per year. In addition, the number of constitutional amendments ranges between 10 and 45 annually. The relatively high number of constitutional modifications (i.e., amendments and new constitution together) creates some room for change in the number of constitutional rights. In total, 122 countries have changed their number of constitutional rights between 1960 and 2011.

Because of the availability of data on the control variables, the sample size of the empirical investigation (section 4.3) is reduced to 73 countries between 1960 and 2011 for the PWT data. Figure 2 in the appendix displays the average number of constitutional rights for three samples: the Full Sample, which includes all countries coded by Elkins et al. (2013), the Variation Sample, which corresponds to the sample of countries whose number of rights has changed since 1960 (122 countries), and the Data Sample, which is the sample of countries for which we have all explanatory variables, including the government size of the PWT data, and which and that have experienced variations in the number of rights. Figure 3 displays the same graph for the World Bank Data.

With regard to the three samples, we can observe that they share a common trend. Indeed, we do not detect any distortion in the number of rights by considering only countries that experienced variations and for which control variables are available. We present descriptive statistics of the Data Samples in the appendix (table 3) for both PWT and World Bank datasets.

Remark 1 Focusing on the countries that have changed their number of constitutional rights since 1960 and for which we have additional data does not create a distortion in the number of constitutional rights compared to the full set of countries.

\subsection{Choosing How to Change the Constitution}

Countries that alter their constitution might not be a random sample of the entire set of countries. Indeed, more stable countries may be less likely to modify their constitution because their constitutional system is more entrenched and therefore more costly to modify (Levinson (2011)). On the contrary, unstable countries may write new constitutions more frequently because new constitutions might serve as de jure legitimations of the new empowered authority. For instance, Albertus and Menaldo (2012) have shown the importance of establishing constitutions in autocratic countries.

Looking at constitutional changes since 1960, we observe two distinct patterns for OECD and non-OECD countries. OECD members in 2012 have been much more likely to amend their con-

\footnotetext{
${ }^{8}$ LGDP, LPOP and OPEN were obtained from the Penn World Tables (Feenstra et al. (2013)). POP14 and POP65 were obtained from the World Bank Database.

${ }^{9}$ POL was imported from the Polity 2 index computed by the Polity IV Project. We recoded the variable into a 0 to 20 scale.
} 
Table 1: New constitutions and constitutional amendments between 1960 and 2012 per OECD status in 2012.

\begin{tabular}{lcc}
\hline \hline & \multicolumn{2}{c}{ OECD Status } \\
\cline { 2 - 3 } $\begin{array}{l}\text { \% which wrote at least one } \\
\text { constitution since 1960 }\end{array}$ & $43.8 \%$ & Not Member in 2012 \\
$\begin{array}{l}\text { \% which amended at least once } \\
\text { their constitution since 1960 }\end{array}$ & $93.8 \%$ & $90.7 \%$ \\
$\begin{array}{l}\text { Average frequency a new } \\
\text { constitution was written }\end{array}$ & $1.6 \%$ & $4.9 \%$ \\
$\begin{array}{l}\text { Average frequency the } \\
\text { constitution was amended }\end{array}$ & $27.7 \%$ & $14.4 \%$ \\
\hline \hline
\end{tabular}

stitution and much less likely to write a new constitution than non-OECD countries. ${ }^{10}$ Table 1 displays some statistics about constitutional amendments and new constitutions. First, it appears that OECD members were much less likely to write a new constitution between 1960 and 2012 . Indeed, only $43.8 \%$ of them did so, while approximately $90.7 \%$ of the non-OECD countries did it in the same period. Second, it seems at the first sight that both OECD and non-OECD countries were equally likely to amend their constitution: approximately $93.8 \%$ of the OECD members amended their constitution at least once, compared with $91.4 \%$ for the non-OECD countries. However, OECD members amended their constitution much more often: on average, OECD members amended their constitution in $27.7 \%$ of the periods considered, i.e., almost once every four years. In contrast, non-OECD countries amended their constitution once every seven years (14.4\%).

Remark 2 Non-OECD countries were more likely to change their constitution by writing a new constitution. On the contrary, constitutional changes in OECD countries were mostly achieved through constitutional amendments.

\subsection{Constitutional Rights Since 1960}

We now investigate which rights have been the most likely to be adopted or removed between 1960 and 2012. Table 2 in the appendix provides three sources of data. The first column indicates the percentage of constitutions in force in 1960 that specified each of the 74 rights. The second column displays the same information for constitutions in force in 2012. The third column computes the difference between the two percentages to show the adoption trend of each right. Positive scores reflect rights that were more likely to be adopted between 1960 and 2012, while negative scores are associated with rights that were more likely to be dropped.

First, one can note that no right has been massively dropped during this time period. This indeed reflects the global trend toward rights inflation depicted by Elkins et al. (2013). A few rights have lost influence over time: the right to bear arms was inscribed in less than $2 \%$ of the

\footnotetext{
${ }^{10}$ We compare the set of countries that were OECD members in 2012 and the set of countries that were not OECD members in 2012 .
} 
constitutions in force in 2012, while it was mentioned in $5.8 \%$ of them in 1960; the right to be judged by a jury was written in $26.7 \%$ of the constitutions in force in 1960 , but was mentioned in only $17.2 \%$ of those in force in 2012 .

On the contrary, a great number of rights have gained in influence in the last five decades. The most popular rights have been negative rights as defined in the above section: the prohibition of cruel, inhuman, or degrading treatment $(+48.7$ percentage points $)$, the right to a fair trial $(+37.2)$, and the freedom of movement $(+38.5)$. Nevertheless, positive rights have also experienced a fair increase: the state's duty to protect or promote culture $(+30.3)$, the right to counsel if one is indicted $(+43.7)$, the right to health care $(+26.8)$, the right to a safe/healthy working environment $(+17.4)$, and the right to shelter or housing $(+17.4)$.

In 2012, the most popular rights were negative rights: the freedom of expression or speech $(93.8 \%$ of the constitutions in force), the freedom of assembly (92.8\%), the freedom of religion (92.2\%), the freedom of association (92.2\%), the freedom of movement (85\%), and the right of privacy (83.9\%). On the other hand, the most popular positive rights were less consensual: the state duty to protect or promote culture $(61.7 \%)$, the right to health care $(48.9 \%)$, or the right to just remuneration, fair compensation $(47.2 \%)$.

\subsection{Constitutional Changes and Government Size}

To take an initial look at the relationship between the number of rights and government size, we consider the level and the evolution of government size at the time the number of rights in a constitutional system is changed. To do so, we consider periods of constitutional changes that led to variations in the number of constitutional rights, and we analyze the level of public expenditure before and after the change for three categories of countries.

Figure 4 displays the evolution of the level of expenditures of the central government where there was a change in the number of constitutional rights. We consider the size of the state five years before and five years after a constitutional change (either due to a new constitution or to an amendment) that induced a change in the number of constitutional rights. To isolate the effect of the targeted change, we keep only countries that did not modify their constitution in the five years preceding and five years following the change. To insure cross-country comparability, we normalized the level of expenditures at 100 five years before the constitutional change. Moreover, to avoid averages with different samples, we keep only countries for which we have data during the entire period.

The graph displays the evolution of government expenditure for three groups of countries: countries that decreased their number of rights (group 1), countries that slightly increased their number of rights (from 1 to 6 additional rights - group 2), and countries that greatly increased their number of rights (more than 7 -group 3). ${ }^{11}$

Figure 4 yields interesting results. First, one can observe that the second and the third groups, i.e., countries that increased their number of constitutional rights, display similar trends prior to the constitutional change: both groups have increased, on average, their public expenditure by approximately $5 \%$ in five years. On the contrary, countries in the first group, i.e., those that decreased their number of rights, have experienced a much larger growth in the level of public expenditure in the five years preceding the constitutional change.

Second, one can note that all categories have increased their expenditures in the two years following the constitutional change. Surprisingly, countries that decreased their number of rights experienced, on average, a constant growth in public expenditure. This result tends to be in contradiction to the hypothesis discussed in the section above. Nevertheless, countries that considerably

\footnotetext{
${ }^{11}$ The threshold of 7 was defined to have balanced groups.
} 
increased their number of rights (group 3) endured the greatest increase in public expenditure five years after the reform. ${ }^{12}$ The greater increase in the level of expenditure incurred by group 3 is in line with the hypothesis we aim to test.

To confirm that these initial results are not solely driven by the considered range (i.e., five years before and five years after the change), we also display the same figure for the period four years before and four years after the change. Looking at figure 5, it appears that the two preliminary observations are reinforced: the increase in public expenditure for countries that increased their number of rights is even more obvious.

Preliminary observations (i) Countries that decreased their number of constitutional rights experienced a considerable increase in their level of expenditure prior to the constitutional change.

(ii) Countries that considerably increased their number of constitutional rights experienced the greatest increase in public expenditure after the constitutional change.

\section{Econometrics}

To investigate the relationship between the number of constitutional rights and the size of government, we proceed in three steps. First, we analyze states' decisions of whether to change their number of constitutional rights. Second, we address states' choices to increase or decrease their number of constitutional rights. Finally, we propose to estimate the causal impact of constitutional rights on the size of government.

\subsection{Choosing to Change the Number of Constitutional Rights}

In the first step, we analyze which countries have changed their number of constitutional rights since 1960. This investigation addresses the issue of sample selection because more stable constitutions might be correlated with some important factors, such as greater political stability or better provision of public goods.

To answer this question, we run a probit estimation on the probability of a country to have changed its number of constitutional rights between 1960 and 2012 (subject to the availability of data for the control variables). We find that 122 of the 182 countries in our database have changed their number of constitutional rights at least once since 1960. However, due to the limited availability of data on the independent variables, we are only able to run probit estimations for 114 countries, among which 76 have changed their constitution since 1960.

The latent utility model associated to the probit estimation is expressed as follows:

$$
C H_{i}^{*}=\beta_{1} \overline{S I Z E_{i}}+\beta_{2} \overline{R I G H T S_{i}}+\beta_{3} \overline{X_{i}}+u_{i}
$$

where $C H$ stands for change (1 if country $i$ changed its number of constitutional rights at least once, 0 otherwise), SIZE $E_{i}$ is a measure of government size, RIGHTS $S_{i}$ corresponds to the number of rights, $X_{i}$ is a vector of control variables, including a constant ${ }^{13}$, and $u_{i}$ is a normally distributed random term. The bar above the independent variables indicates that the variables have been

\footnotetext{
${ }^{12}$ The average score of public expenditure for group 1 went from 120.3 to 127.8 between the year of constitutional change and five years after the change, which corresponds to an increase of $5.4 \%$. Concerning the third group, the score increased from 103 to 113.8, which is equivalent to an increase of $10.5 \%$.

${ }^{13}$ It includes: the number of years the constitution has been in force, the ratification status of the ICCPR, the log of the GDP per capita, the log of the population, the level of openness, the polity2 score, a proxy for human capital, the share of the population below 14 years old, and the share of the population above 65 years old.
} 
transformed.

We present three sets of results in table 4 depending on the transformation of the independent variables we consider. First, we consider the country average value of the independent variables for all available observations between 1960 and 2012. Second, we use the value of the first time we observe the independent variable in our dataset for each country. Third, we use the latest value of the independent variables for each country. Moreover, for each specification, we estimate the probit model by using both the PWT and the World Bank data separately.

Three main results emerge from table 4. . First, considering the second specification (columns 3 and 4), we can observe that countries that had many rights at the beginning of the period were less likely to change the number of rights during this same period. This observation might reflect a catching-up effect: because of the overall increase in human rights during the second half of the 20th century (as shown by Elkins et al. (2013)), countries with few constitutional rights might have been pressed to catch up, and thus to increase their number of constitutional rights. Second, we also observe that countries that have been the most likely to change their number of constitutional rights were also the least democratic countries in 1960. Given that the effect of POL is not significant in the third specification, it follows that the current level of democracy does not matter. Altogether, these two observations might suggest that countries that have changed their number of constitutional rights have also improved their democratic situation. To confirm this prediction, we compute the change in the democratic score between the first and the last year of observation for countries that changed their number of rights and those that did not. A two-group mean comparison test on 157 countries rejects the null hypothesis, and confirms the previous finding: countries that changed their number of rights also improved their democratic situation. ${ }^{14}$ Third, we also observe that the current population is positively associated with the probability of a change in the number of constitutional rights. It indicates that more populated states have been more likely to change their number of rights. This result per se is difficult to interpret because the coefficient associated with the average and the first values are not significant.

Results 1 Countries that have changed their number of constitutional rights:

(i) had fewer constitutional rights in 1960, which suggests that they have sought to catch up on the number of constitutional rights; and

(ii) improved their democratic situation between 1960 and 2012.

\subsection{Choosing the Number of Constitutional Rights}

The previous section has shown that the countries that changed their number of rights are not random. A second question arises regarding the direction and the intensity of these changes: which factors influence the number of constitutional rights?

Constitutional changes are costly political events, as they require either a large consensus to modify the constitution in democracies or strong resources to impose new institutions by force in authoritarian regimes. Factors that may call for a high or low level of constitutional rights might also influence the opportunity for constitutional change itself. In other words, we observe changes in the number of constitutional rights only when the underlying factors affecting the number of

\footnotetext{
${ }^{14}$ The bilateral two-group mean comparison test rejects the null hypothesis at the $99 \%$ confidence level. Countries that did not change their number of rights improved their democratic situation by 1.83 points, on average, against 4.89 for those that did change their number of rights.
} 
constitutional rights are strong enough to lead to a modification of the constitution (either by amendment or by creating a new constitution).

It follows that estimating the impact of some independent variables on the choice of the number of constitutional rights only when changes occurred would suffer from sample selection issues. Therefore, we propose to explain choices of the number of constitutional rights by controlling for the selection step, i.e., the probability of modifying the constitution. To do so, we use a Heckman procedure. The equation of the number of rights is as follows:

$$
R I G H T S_{i t}=\gamma_{1} S I Z E_{i, t-1}+\gamma_{2} X_{i, t-1}+v_{i t}
$$

where $S I Z E_{i, t-1}$ is the size of the government at time $t-1, X_{i, 1 t}$ is the lag value of the same vector of control variables as in equation (1) plus a linear time trend, and $v_{i t}$ is a zero-mean random term. We consider lag values of the control variables to avoid endogeneity issues.

The latent utility model of the selection equation is expressed as follows:

$$
C H_{i t}^{*}=\phi_{1} S I Z E_{i, t-1}+\phi_{2} X_{i, t-1}+\phi_{3} P R E S S_{i, t-1}+\epsilon_{i t}
$$

where $\epsilon_{i t}$ is a normally distributed random variable.

Identification of the Heckman model is achieved by having at least one independent variable included in the selected step, which is not included in the main equation. In our case, it requires a variable that influences the probability of modifying the constitution but that does not determine the number of constitutional rights. Our specification uses the variable $P R E S S_{i, t-1}$ as an instrument. This variable is equal to the difference in the number of rights between country $i$ 's constitution and the average number of rights in the world. It represents the pressure for constitutional modification: the greater the value of this variable, the more outdated a constitution might be and, therefore, the more likely the country is to modify its constitution. Therefore, we expect this variable to be correlated with the selection step. Moreover, we believe that this variable does not directly affect the number of rights. When choosing the number of rights, constitution-makers do not consider the previous gap between the former constitution and the previous average number of rights in other countries; rather, they take into account the entire set of rights that are 'available': the larger the set of rights that have been acknowledged by other constituencies, the more rights there are available to inscribe in a constitution. The linear trend in our specifications aim at capturing this inflation of rights. As we comment below, this trend is indeed highly significant and is in line with Elkins et al. (2013).

Table 4 displays the results of a series of estimations with the PWT data. ${ }^{15}$ The first column displays the results of an OLS estimation of equation (2) considering all observations of countries that changed their number of constitutional rights at least once since 1960. The second column shows the result of the same estimation, but considers only observations when the constitution was amended or when a new constitution was written. The third column corresponds to the previous estimation, but considers only observations when the number of rights was modified. The fourth

\footnotetext{
${ }^{15}$ We run the estimations for the World Bank data as well. The results for the OLS estimations were nearly identical. Because of the reduced availability of the data and the high number of censored data in the Heckman estimation, convergence was very difficult to obtain for the Heckman estimation. However, subspecifications (excluding some independent variables) indicated similar results.
} 
and fifth columns correspond to the first and second steps of the ML Heckman estimation, where the number of rights is estimated only when constitutional change occurs and when the number of rights is changed.

First, comparing the general performance of our regressions, we can observe that the first two columns yield very similar results. The third and the fourth columns also display findings close to the two previous columns, except for DUR, ICCPR,LPOP, and POP65. The Heckman estimation finds a very high correlation coefficient between the error terms of the selection and the main equations (resp. equations 3 and 2). This suggests that selection does occur, i.e., that changing the number of constitutional rights is not independent of the number of constitutional rights a country decides to inscribe in the constitution.

The results of these estimations are very similar with regard to the main variable of interest, i.e., the size of government. The three OLS specifications detect a negative impact of the size of government on the number of rights. The Heckman specification confirms that this effect is not affected by the selection step: the size of the government does not influence the probability of changing the number of constitutional rights, but does influence the number of constitutional rights one inscribes in the constitution. This finding suggests that endogeneity might be a major concern when estimating the impact of the number of constitutional rights on government size. We can note, however, that the specifications in table 4 do not include country fixed effects because of the small number of changes in the number of rights. It might be that countries with a strong involvement of the state (such as Norway) inscribe fewer rights in their constitution (for instance because of their well-developed case law), but that variations of wealth within a country might not influence the number of constitutional rights. In all, our results suggest that endogeneity might be an issue, but we cannot draw that conclusion too rapidly.

As far as the remaining variables are concerned, we observe that wealthier countries inscribe more rights in their constitution. The coefficient associated to TREND is positive and statistically significant: it captures the fact that constitutional rights have inflated over the second half of the 20th century. The two first specifications also detect that younger constitutions, i.e., those that have been in place for only few years, contain fewer rights. The specifications also reveal that countries that ratified the ICCPR and those that have a small share of old citizens are more likely to have constitutional rights. Finally, the selection step of the Heckman specification shows that more populated countries are more likely to change their number of constitutional rights.

Results 2 The size of government (i) does not affect the probability of changing the number of constitutional rights, (ii) but determines the number of constitutional rights: countries with larger governments tend to put fewer rights in their constitution.

The negative impact of the size of government on the number of rights might appear surprising at first sight. Indeed, countries with larger governments should be used to state intervention, and citizens should therefore trust the state to undertake further duties. One could also think that larger governments are de facto providing some constitutional rights, and citizens should seek to recognize ex post the state's duties in their constitution. Both propositions should induce a positive relationship between the size of government and the number of rights. On the contrary, we observe that larger governments are associated with fewer rights. From an economic perspective, this observation might result from decreasing returns on state intervention: political actors might seek to reduce the intervention of the state (which is costly because of increasing organizational costs) by limiting the number of rights in their constitution. This would account for the negative relationship depicted by the data. Similarly, one could also argue that larger governments already 
result from an extensive case law developed by higher courts and that such governments do not see the necessity of inscribing in their constitution rights they already provide.

\subsection{Impact of the Number of Constitutional Rights on Government Size}

The discussion of section 2 predicts a positive impact of the number of constitutional rights on the size of government. To assess the empirical validity of this claim, we need to tackle some empirical challenges, i.e., sample selection and two endogeneity issues (unobserved heterogeneity and feedback effect).

\subsubsection{Estimation Strategy}

The investigation of the impact of constitutional rights on the size of government must address three empirical issues. First, it might be that countries have different inherent propensities to have constitutional rights and to have large governments, which might lead to unobserved heterogeneity. This problem is equivalent to an omitted variable problem, which may lead to endogeneity concerns. To isolate the effect of the number of constitutional rights, we need to focus on the changes in the number of rights in each country. To do so, we exploit the panel structure of our dataset and include fixed effects. Second, it may also be that countries that have changed their number of rights are a specific subsample of countries: evaluating the impact of constitutional rights on this subsample might be misleading. The first subsection of the current section investigated this issue (see results 1). Sample selection might also come from the independent variables used in our estimations. We discuss the potential bias that arises from this below. Third, the last subsection showed that the size of government might also determine the number of constitutional rights, leading to potential feedback effects (endogeneity) if the number of rights has an effective impact on government size. In the following paragraphs, we develop an empirical strategy to address both of these endogeneity concerns (unobserved heterogeneity and feedback effects).

Unobserved heterogeneity To address unobserved heterogeneity, we rely on fixed effects specifications. Previous works in constitutional political economy have also taken advantage of the panel structure of their data to cope with unobserved heterogeneity. However, these works have faced a strong econometric challenge: constitutional rules experience very few variations over time. In constitutional political economy, and more globally in political science, this problem is known as the iron law. Past works have addressed this issue in three ways. First, some authors have used random effects models, which all assumed strict exogeneity between the individual effects and the regressors (Gutmann and Voigt (2013)). Such investigations usually lead to doubtful results because they often fail at fulfilling the exogeneity condition, leading to biased and inconsistent estimators. Second, some authors have averaged data over time and have run cross-section regressions (Melton and Ginsburg (2014)). Such analyses do not take advantage of the panel structure of the data and are therefore as informative as simple cross-section investigations. Third, some other papers have dropped observations to implement fixed effects procedures. The main disadvantage of this last strategy lies in the potential selection bias between countries that experienced constitutional changes and countries that did not.

Our empirical strategy relies on a fixed effects approach. While the iron law turns out to be a major concern when one focuses on some specific constitutional rules (e.g., whether the government can be dismissed by the Parliament), it has a much more limited impact on our rights variable, which aggregates several rights. In fact, although the probability of changing one particular right 
may be very low, the total probability of changing at least one right in the 50-year period is much higher.

Sample Selection To run fixed effects estimations, we consider only countries whose number of constitutional rights varied in the period for which we have data. To do so, we selected countries whose constitution has been either amended or changed between the first year of observation of the dependent variable and 2012, such that the number of rights has varied in the time period we consider (subject to data availability). Because our investigation relies on two dependent variables, we obtained two samples of countries. ${ }^{16}$

Section 3 has presented some stylized facts about constitutional changes since 1960. It showed that 122 countries have changed their number of constitutional rights between 1960 and 2011. Because of the availability of data on the control variables, the sample size was reduced to 73 countries between 1960 and 2011 for the PWT data and to 69 countries for the WB data. We present descriptive statistics of the two regression samples in the appendix (table 3 ).

General Specification Our general econometric model is as follows:

$$
S I Z E_{i t}=T_{i t}^{\prime} \beta+R I G H T S_{i t} \gamma+\alpha_{i}+\mu_{t}+\epsilon_{i t}
$$

where $S I Z E_{i t}$ denotes the relative size of the government as the share of GDP, $T_{i t}$ is the vector of control variables for country i at year $\mathrm{t}$, including a constant ${ }^{17}$, RIGHTS $_{i t}$ is the number of rights in country $i$ 's constitution at year $\mathrm{t}, \alpha_{i}$ is the country fixed effect, and $\mu_{t}$ is the year fixed effect.

Feedback Effects The main challenge of our investigation concerns the potential source of a feedback effect. In fact, a global consensus has emerged in constitutional political economy and, more globally, in the new institutional economy, to recognize that institutions are endogenously selected. ${ }^{18}$ Constitutions are often written either by constituent assemblies or by the executive or legislative branch themselves (Ginsburg et al. (2009)), which de facto excludes quasi-natural experiments.

As far as our investigation is concerned, feedback effects would arise if government size and the number of constitutional rights were influencing each other. The above subsection showed that the lag value of government size is associated with a negative and significant effect on the number of constitutional rights. To determine whether the number of rights effectively affects the level of public expenditure, we need to anticipate such potential feedback effects.

The general solution for such feedback effects consists of relying on instrumental variables, which must fulfill two criteria: they must first influence the number of constitutional rights, but they also need to be uncorrelated with the degree of state intervention. ${ }^{19}$

We propose three instruments that, in our view, fulfill these two criteria.

\footnotetext{
${ }^{16}$ Because our estimation relies on instruments, we need to get rid of countries that did not experience variations in the number of constitutional rights. The first stage estimation would otherwise create artificial variations for the instrumented variable.

${ }^{17}$ It includes variables contained in $X$ (previous subsection) and variable LOPOL (see below).

${ }^{18}$ As Blume et al. (2009) state: "Institutions are man-made which means that there is always a potential endogeneity problem that needs to be dealt with." (p. 203)

${ }^{19} \mathrm{~A}$ more rigorous statement would be that instruments must be uncorrelated with the error term of equation (4), i.e., with government size that is not explained by the remaining independent variables.
} 
First, we propose two instruments that account for international pressure when amending or changing a constitution. As Elkins et al. (2013) shown, worldwide practices greatly influence domestic constitutional design.

On the one side, we claim that constitutions are written in the light of previous and contemporary constitutional systems. We believe, therefore, that the date at which a constitution is written has an impact on the number of constitutional rights: when one amends a constitution in 2015, one is more likely to introduce constitutional rights than one century ago because the very notion of human rights has expanded to include many additional dimensions. We propose to capture this idea by considering the worldwide average number of rights in constitutions the year before country $i$ modified its constitution. We denote the corresponding variable $C H \_W A R$ (WAR stands for worldwide average rights, and $C H$ for change because its value is set one year before the last constitutional modification).

On the other side, we aim to capture a second dimension of international pressure, namely, the de facto situation of human rights in influencing countries. In our view, when countries decide to change the content of their constitution, they are influenced by the democratic situation in similar legal systems. As Goderis and Versteeg (2013) have shown, countries are more likely to follow constitutional choices made by countries that share the same legal origin. Their analysis even concluded that legal origin is the most important predictor of constitutional diffusion. They argue that "constitution-makers borrow from states with which they already share important preexisting legal similarities" (Goderis and Versteeg (2013), page 2). For this reason, we consider the influence between countries that share the same legal origin (Glaeser and Shleifer (2002), Glaeser et al. (2004)). We postulate that the de facto democratic situation in countries that share the same legal origin influences the choices to inscribe constitutional rights in a constitution: the more democratic similar countries are, the stronger the democratic pressure is, and therefore, the more likely the countries are to include constitutional rights. To account for this phenomenon, we generate a variable $\mathrm{CH}_{-} L O P O L$ (where $L O$ stands for Legal Origin and $P O L$ for the polity2 score). Because the democratic situation of the similar countries might have an impact on the level of public expenditure, we control in the main equation and in the first stage by the contemporaneous value of $L O P O L$.

Third, we consider the nature of the authority that drafted the constitution. Ginsburg et al. (2009) found that the drafters' identity matters for constitutional design. We thus use the nature of the authority that wrote the constitution to proxy the number of constitutional rights. In our view, the identity of the drafters is very likely to influence the number of constitutional rights because of the strategic behaviors of the political actors. Indeed, we believe that whenever the constitution is written by one of the existing branches of power (i.e., the executive or legislative branch), it will include fewer rights because such drafters would be reluctant to constrain themselves in the future. We create a variable DRAFTER, which is equal to 1 when the constitution was not drafted by the executive or the legislative in place (e.g., when a constituent assembly was elected), and 0 otherwise. ${ }^{20}$

Because these two variables aim to instrument the number of rights, we freeze the instruments at the date of the last constitutional modification (amendment or new constitution). Using contemporaneous values of the instruments would indeed lead to biased estimations because the instruments would approximate the number of rights that would have been in the constitution if it were revised in the present year. For instance, Albania changed its constitution in 1998. To instrument the number of rights in 1999 and the following years, we take the value of our instruments in 1998.

\footnotetext{
${ }^{20}$ The variable DRAFTER focuses only on the drafting procedure of new constitutions. It is therefore not modified when a constitution is amended. For instance, a constitution originally drafted by a constituent assembly but modified by the legislative branch will keep a DRAFTER score equal to 1.
} 
Altogether, the first stage of our estimation for the number of rights is:

$$
R I G H T S_{i t}=T_{i t}^{\prime} \phi+Z_{i t}^{\prime} \sigma+\xi_{i}+\nu_{t}+u_{i t}
$$

where $T_{i t}$ contains the same variables as in the second stage equation, and $Z_{i t}$ includes $C H_{-} W A R$, CH_LOPOL and DRAFTER. We rely on both 2SLS and GMM estimates.

To further assess the validity of our instruments, we run a series of specifications and, for each of them, report the results of the underidentification test, the weak identification test, and the overidentification test. We reject a test's null hypothesis when the test's p-value is lower than 0.05. For the overidentification test, we report the p-value when it is higher than 0.05. Concerning the weak identification test, we present both the highest Stock-Yogo statistics and the corrected F-statistics. ${ }^{21}$

\subsubsection{Results}

Table 6 shows the results of the within OLS and IV estimations of equation 4 for the Penn World Table Data. Column 1 displays the results of the OLS estimation. Columns 2 to 5 include the estimates of the IV estimation for both GMM and 2SLS procedures. The specification of column 2 includes all instruments, and columns 3 to 5 each exclude one instrument. The exclusion of instruments is motivated by the tradeoff between the overidentification test, which requires a large number of instruments, and the weak identification test, which prefers fewer but stronger instruments. All specifications pass the underidentification test, which indicates that our instruments are indeed correlated with the instrumented variable. The specifications of columns 3 and 5 both yield Kleibergen-Paap F-statistics that are above the $15 \%$ Stock-Yogo statistics, which suggests that the set of instruments in these two specifications is sufficiently correlated with the instrumented variable, i.e., the number of rights. No specification rejects the null hypothesis of the overidentification test, which indicates that our instruments satisfy the exclusion restriction. Finally, and more surprising, our estimations fail at rejecting the null hypothesis of the endogeneity test, which suggests that the IV estimates are statistically not different from the OLS estimates. Table 7 displays the same estimates for the World Bank Data. Table 8 and 9 display the estimated coefficients associated with the instruments of the first stage IV within estimations of tables 6 and 7.

Results displayed in tables 6 and 7 are similar and fail at detecting any impact of the number of rights on government size. None of the coefficients associated to RIGHTS is found to be significant. The 2SLS and GMM estimates are very close and conclude in the same way. Moreover, the fact that the PWT and the WB datasets yield estimates with opposite signs seems to confirm the null hypothesis, i.e., that the number of rights does not have any impact on government size.

Differentiation By Democratic Situation Past works on international human rights treaties have determined that the marginal impact of human rights treaties on the human rights situation was conditional based on the level of de facto democracy in the ratifying countries. We investigate the relevance of such theories in the case of constitutional rights. To do so, we compute the conditional impact of constitutional rights with respect to the level of democracy in the country

\footnotetext{
${ }^{21} \mathrm{~A}$ specification passes the weak identification test if the corrected F-statistics is higher than the reported StockYogo statistics.
} 
under consideration. We start by computing country $i$ 's average level of de facto democracy in the three past years $(A V P O L)$. We then multiply this variable with $R I G H T S$ to obtain an interaction variable $I N T \_R I G H T S$. Third, we multiply our instruments with $A V P O L$ to obtain interaction instruments (see Balli and Sørensen (2013)).

The results of this new set of specifications are displayed in tables 10 and 11 . Because of the duplication of our instruments, the F-statistics associated with the weak identification test decreased in the specification including all instruments. Columns 6 and 7 reduce the number of instruments, as to maximize the F-statistics and to decrease the Stock-Yogo requirements. The specification of column 7 appears to be the most suitable specification.

Figures 6 and 7 propose graphical interpretations of these results. For both figures, the upper graphs correspond to the marginal effect when using 2SLS techniques, while the two lower graphs display the marginal effect of constitutional rights when estimated with GMM techniques. The graphs on the left are associated with the three-instrument specification (column 6 of the above table), while the graphs on the right show the results for the two-instrument specification (column 7).

Here again, the results of the different specifications yield the same conclusion: the impact of constitutional rights is not significantly different from zero, regardless of the democratic situation of the country. ${ }^{22}$ In addition, all specifications depict a positive impact of the democratic level on the marginal effect of the number of constitutional rights; however, this increase is statistically significant in only a few specifications (specification 5 of table 10, specifications 2, 3, 4 and 5 of table 11).

Robustness Check: Focus on More Demanding Rights Focus on More Demanding Rights The above estimation concludes that the number of constitutional rights does not have a significant effect on the size of government. Several explanations may account for these findings. More particularly, one potential concern could result from the scope of rights considered by our RIGHTS variable. One could argue, in fact, that our independent variable of interest includes too many dimensions, which might even have opposite effects on government size. Indeed, although it is quite straightforward that the enforcement of positive rights necessitates a greater involvement of the state, the picture is more complex regarding negative rights. We therefore consider a second indicator, denoted SUB_RIGHTS, which considers only a subset of rights included in the RIGHTS variable, i.e., positive rights only. ${ }^{23}$

The estimation of the previous specification with this new variable yields similar results: the number of constitutional rights does not increase the size of the government. Previous comments on the quality and relevance of our IV estimates also hold for this new estimation. Tables 12 and 13 display the results of this new series of estimations.

\section{Conclusion and Discussion}

This article aimed to investigate the potential impact of constitutional rights on the level of public expenditures. To do so, we used a panel dataset, which includes information about constitutional rights for constitutional systems since 1960. We measured the relationship between constitutional rights and the relative size of the state. We used the share of the government in terms of total GDP

\footnotetext{
${ }^{22}$ The marginal effect is not statistically significant at the $90 \%$ confidence level either.

${ }^{23}$ The list of constitutional rights in our dataset is displayed in table 2 in the appendix. Variable SUB_RIGHTS includes: asylum, conright; couns, cultrght, falseimp, healthf, healthr, provhlth, provwork, remuner, safework, rghtapp, shelter, speedtri, standliv trilang.
} 
as a proxy for the size of the government. First, we investigated which countries were the most likely to have changed their number of constitutional rights since 1960. We found some evidence for a catch-up effect: countries that had fewer rights in 1960 were the most likely to change their number of rights during the subsequent fifty years. Moreover, we also found that countries that improved their democratic situation were also the most likely to have changed their number of constitutional rights. Second, we analyzed whether the size of government influenced the probability that a state changes its number of constitutional rights and whether it affects the number of constitutional rights the state decides to put in the constitution. We found that (the lag value of) the size of government does not affect the probability of changing the number of rights, but negatively affects the number of constitutional rights. Considering this feedback effect, we used an instrumental variable approach to estimate the impact of the number of constitutional rights on government size. To do so, we used a set of three instruments and estimated the causal impact with both GMM and 2SLS methods. We compared our results using two dependent variables.

Our estimations did not detect any causal effect of the number of constitutional rights on government size. Indeed, we did not find any evidence supporting the theory that more constitutional rights induce a stronger commitment by the state, leading to a stronger intervention in the economy. The lack of significance of the coefficient associated with the number of rights was robust to all specifications and to both sources of data. To investigate the lack of significance, we allowed for a conditional causal impact according to the level of de facto democracy. We did not find any evidence of an overall positive impact of constitutional rights on government size. At best, we found some fragile evidence suggesting that constitutional rights are more likely to induce larger governments in democratic countries. Finally, we reduced the number of rights considered in our analysis, to focus exclusively on those that are the most likely to induce a greater intervention by the state. Here again, we failed at detecting an impact of constitutional rights on the level of public expenditure.

Several factors may account for the lack of evidence supporting a positive causal impact of the number of constitutional rights on government size. First, it might be that countries inscribe rights in their constitutions when they already provide these rights, e.g., through statutory laws. The inscription of rights in the constitution would only aim at insulating existing policies. However, this alternative explanation would hardly account for the negative impact of government size on the number of constitutional rights. Second, it might also be the case that constitutions mainly serve signaling purposes: countries do not necessary seek to enforce constitutional rights, but decide to inscribe them in their constitution for other purposes. For instance, autocratic countries might try to mitigate the international pressure regarding human rights violations by changing their constitutions.

The lack of significance might also be due to technical reasons. It might be that our dependent variable $(S I Z E)$ is not appropriate to capture the effect of constitutional rights. The discussion in section 2 has shown that the final consumption of outsourcing governments may not be affected by an increase of constitutional rights due to the private enforcement of these rights. Considering the government's budget rather than its final consumption might help to resolve this issue. The scarcity of data regarding the government's budget, however, would raise other methodological issues. 


\section{References}

Albertus, M. and Menaldo, V. (2012), 'Dictators as Founding Fathers?', Economics 6 F Politics 24, 279-306.

Alesina, A. and Wacziarg, R. (1998), 'Openness, Country Size and Government', Journal of Public Economics 69, 305-321.

Balli, H. O. and Sørensen, B. E. (2013), 'Interaction Effects in Econometrics', Empirical Economics 45, 583-603.

Barak, A. (2012), Proportionality ii, in 'Oxford Handbook Of Comparative Constitutional Law', Michel Rosenfeld and András Sajó eds, pp. 738-754.

Benarroch, M. and Pandey, M. (2008), 'Trade Openness and Government Size', Economic Letters 101, 157-159.

Bergh, A. and Karlsson, M. (2010), 'Government Size and Growth: Accounting for Economic Freedom and Globalization', Public Choice 142, 195-213.

Bjørnskov, C. and Mchangama, J. (2013), 'Do Social Rights Affect Social Outcomes?', Working Paper.

Blume, L., Müller, J., Voigt, S. and Wolf, C. (2009), 'The Economic Effects of Constitutions: Replicating-and Extending- Persson and Tabellini', Public Choice 139, 197-225.

Bose, F. (2010), 'Parliament vs. Supreme Court: A Veto Player Framework of the Indian Constitutional Experiment in the Area of Economic and Civil Rights', Constitutional Political Economy 21, 336-359.

Brambor, T., Clark, W. R. and Golder, M. (2006), 'Understanding Interaction Models: Improving Empirical Analyses', Political Analysis 14(63-82).

Buchanan, J. M. and Tullock, G. (1962), The Calculus of Consent: Logical Foundations of Constitutional Democracy.

Elkins, Z., Ginsburg, T. and Simmons, B. (2013), 'Getting to Rights: Treaty Ratification, Constitutional Convergence, and Human Rights Practice', Harvard International Law Journal 54, 61-95.

Epstein, D. L., Bates, R., Goldstone, J., Kristensen, I. and O'Halloran, S. (2006), 'Democratic Transitions', American Journal of Political Science 50(3), 551-569.

Feenstra, R. C., Inklaar, R. and Timmer, M. P. (2013), 'The Next Generation of the Penn World Table'.

Feld, L. P. and Voigt, S. (2003), 'Economic Growth and Judicial Independence: Cross-country Evidence Using a New Set of Indicators', European Journal of Political Economy 19, 497-527.

Glaeser, E. L. and Shleifer, A. (2002), 'Legal Origins', The Quarterly Journal of Economics 19, 11931229.

Glaeser, E. L., La Porta, Rafael, Lopez de Silanes, F. and Shleifer, A. (2002), 'Do institutions Cause Growth?', Journal of Economic Growth 9, 271-303. 
Ginsburg, T., Elkins, Z. and Blount, J. (2009), 'Does the Process of Constitution-Making Matter?', Annual Review of Law and Social Science 5, 201-223.

Ginsburg, T. and Versteeg, M. (2013), 'Why do Countries Adopt Constitutional Review?', Journal of Law, Economics and Organization.

Goderis, B. and Versteeg, M. (2013), 'The Transnational Origins of Constitutions?', CentER Discussion Paper.

Gutmann, J. and Voigt, S. (2013), 'Constitutional Constraints on the Military?', Working Paper.

Hayo, B. and Voigt, S. (2007), 'Explaining de facto Judicial Independence', International Review of Law and Economics 27, 269-290.

Hayo, B. and Voigt, S. (2013), 'Endogenous Constitutions: Politics and Politicians Matter, Economic Outcome Don't', Journal of Economic Behavior and Organization 88, 47-61.

Holcombe, R. G. and Rodet, C. S. (2012), 'Rule of Law and the Size of Government', Journal of Institutional Economics 8, 49-69.

Law, D. S. and Versteeg, M. (2013), 'Sham Constitutions', California Law Review .

Levinson, D. J. (2011 ), 'Parchment and Politics: The Positive Puzzle of Constitutional Commitment', Harvard Law Review 124, 657-746.

Melton, J. and Ginsburg, T. (2014), 'Does De Jure Judicial Independence Really Matter? A Reevaluation of Explanations for Judicial Independence', Journal of Law and Courts, 187-217.

Neumayer, E. (2005), 'Do International Human Rights Treaties Improve Respect for Human Rights?', Journal of Conflict Resolution 49(6), 925-953.

Persson, T. and Tabellini, G. (2004), 'Constitutional Rules and Fiscal Policy Outcomes', American Economic Review 94(1), 25-45.

Persson, T. and Tabellini, G. (2005), The Economic Effects of Constitutions, MIT Press Books, The MIT Press.

Posner, D. N. and Young, D. J. (2007 ), 'The Institutionalization of Political Power in Africa', Journal of Democracy 18, 126-140.

Ram, R. (2009), 'Openness, Country Size, and Government Size: Additional Evidence from a Large Cross-country Panel', Journal of Public Economics 93, 213-218.

Rodrik, D. (1998), 'Why do More Open Economics Have Bigger Governments?', Journal of Political Economy 106, 997-1032.

Shelton, C. A. (2007), 'The Size and Composition of Government Expenditure', Journal of Public Economics 91, 2230-2260.

Sugden, R. (1993), 'Rights: Why do They Matter, and to Whom?', Constitutional Political Economy 4(1), 127-152.

Voigt, S. (2011), 'Positive Constitutional Economics ii - A Survey of Recent Developments', Public Choice 146, 205-256. 


\section{A Figures}

Figure 1: Number of Constitutional Changes since 1950 (both new constitutions and amendments).

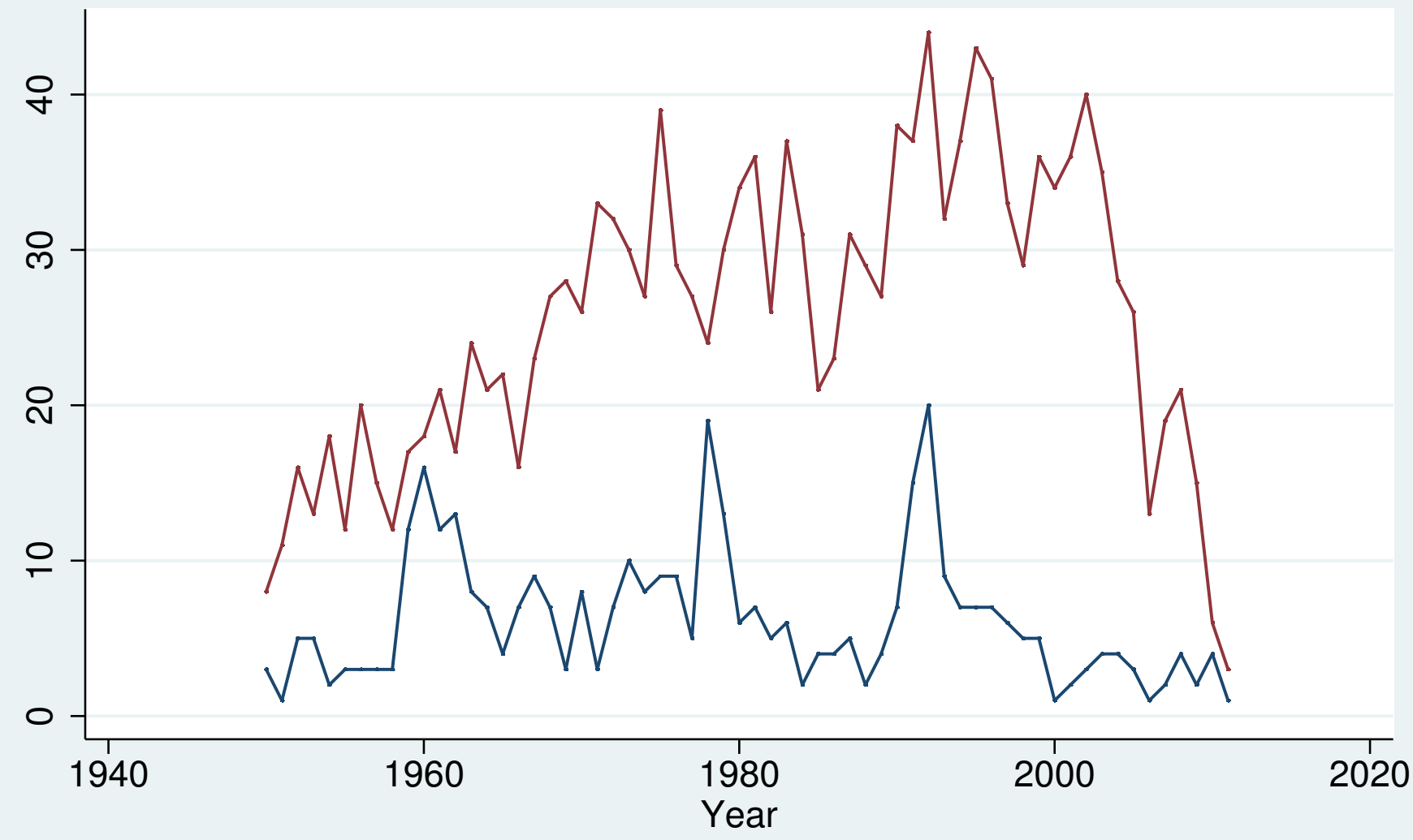

- Number of New Constitutions Number of Constitutional Amendments 
Figure 2: Mean of Constitutional Rights for Full, Variation and Data samples since 1960: PWT Data.

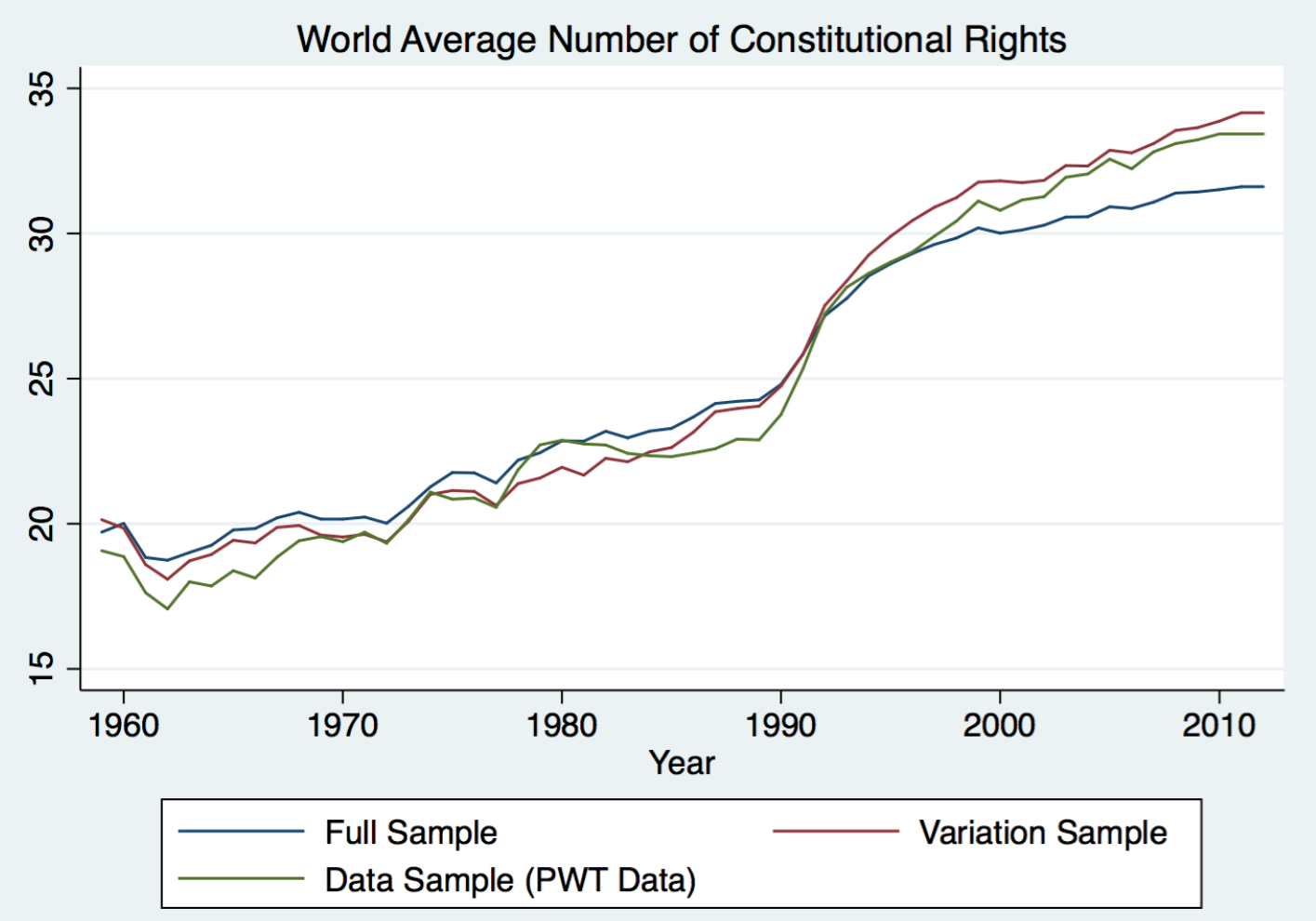

Figure 3: Mean of Constitutional Rights for Full, Variation and Data samples since 1960: World Bank Data.

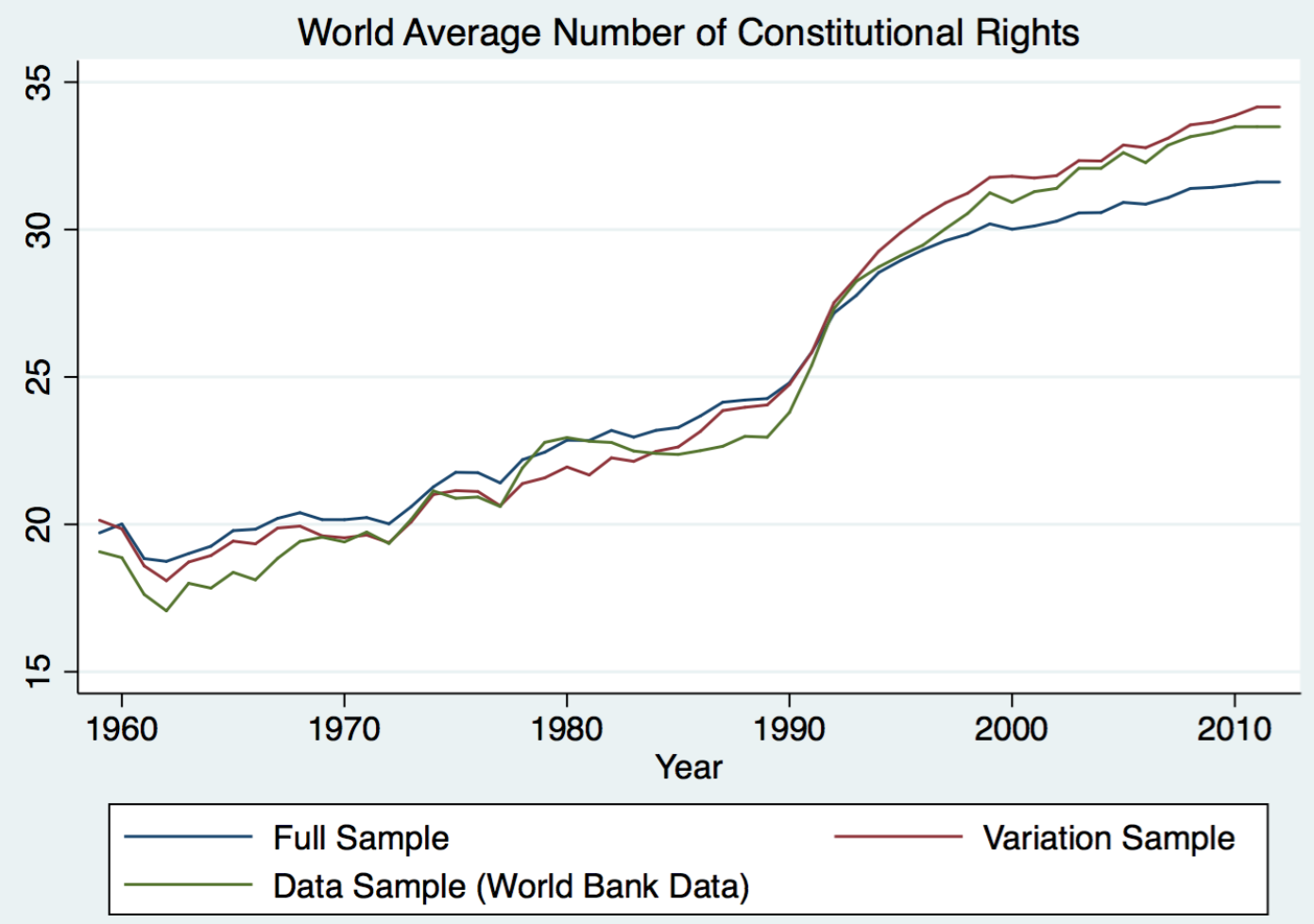


Figure 4: Evolution of the size of government $\mathbf{5}$ years before and $\mathbf{5}$ years after a constitutional change according to the evolution of constitutional rights.

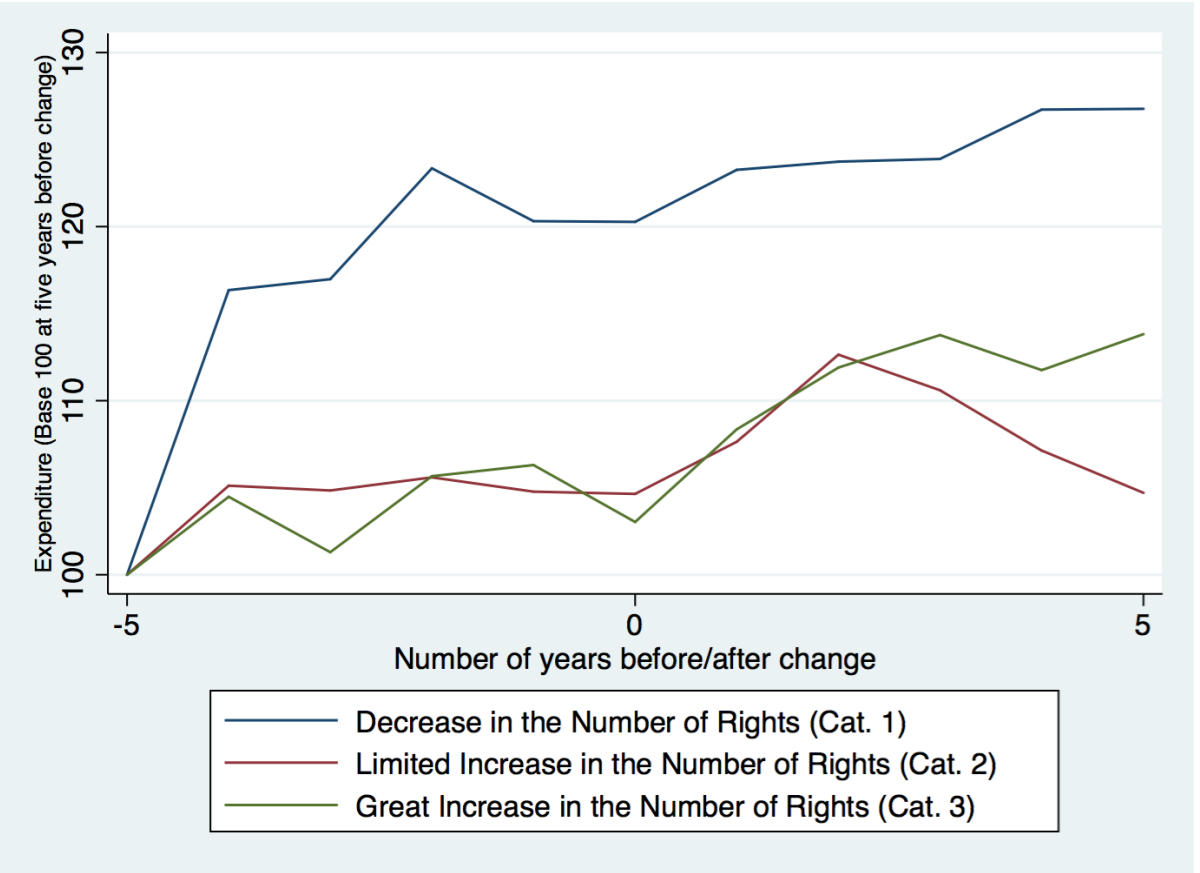

Notes: Constitutional modifications without changes in the number of constitutional rights are excluded.

Figure 5: Evolution of the size of government 4 years before and 4 years after a constitutional change according to the evolution of constitutional rights.

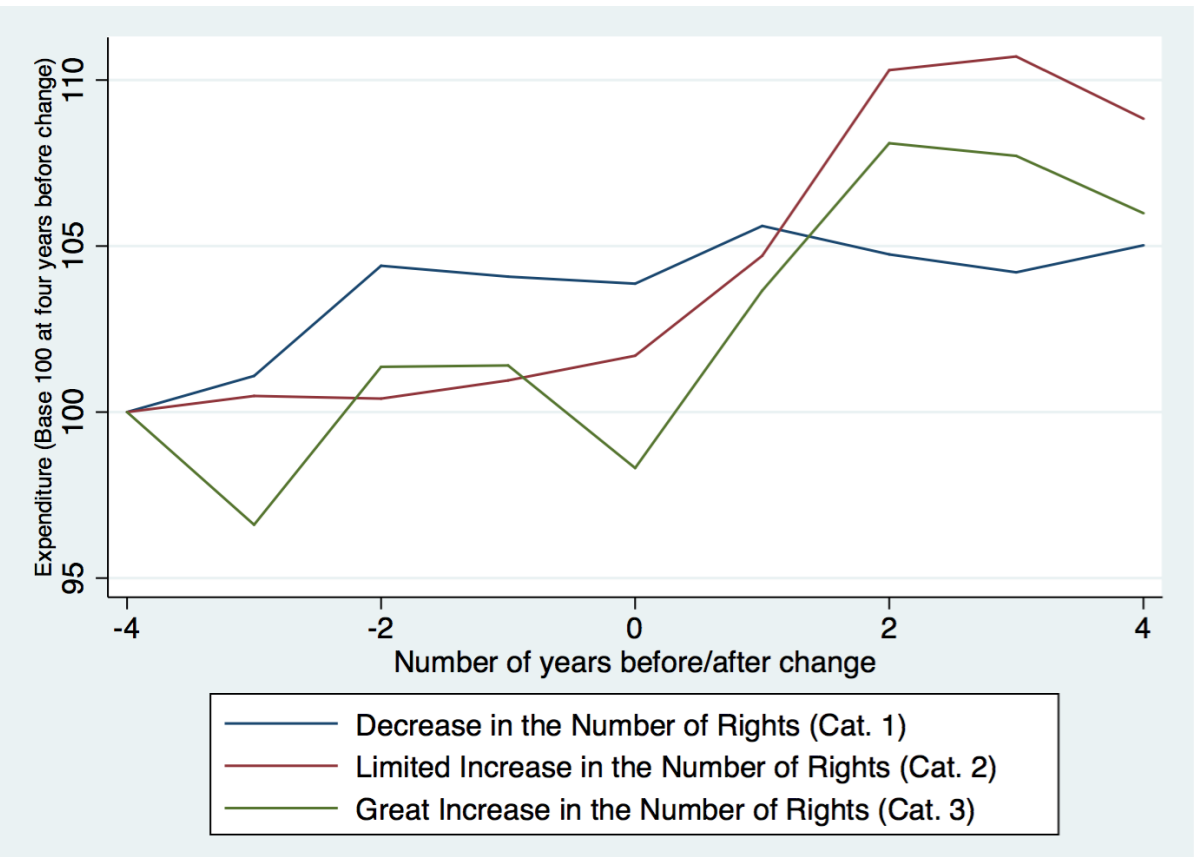

Notes: Constitutional modifications without changes in the number of constitutional rights are excluded. 
Figure 6: Marginal Effect of Constitutional Rights on Government Size (PWT Data).
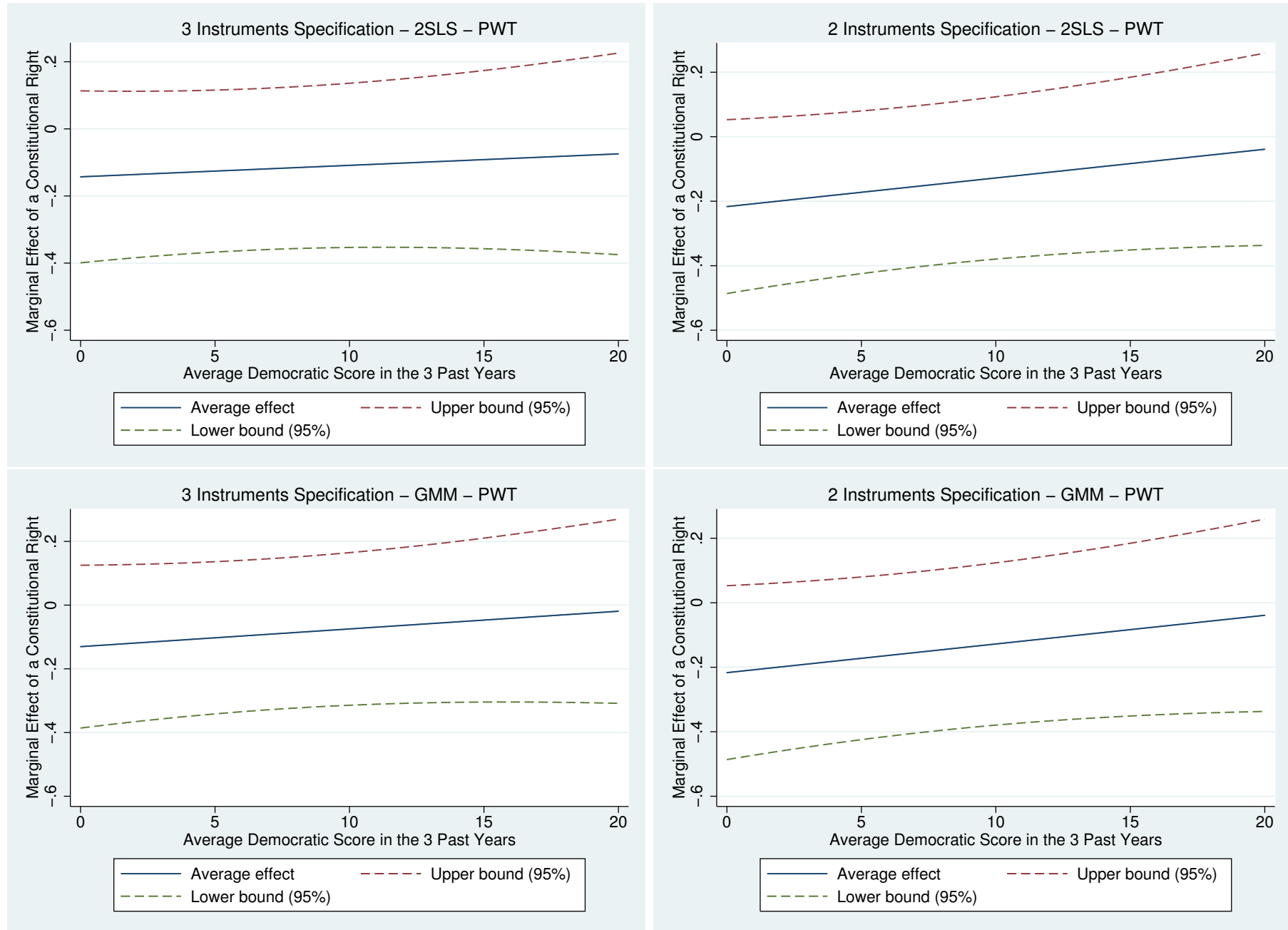
Figure 7: Marginal Effect of Constitutional Rights on Government Size (World Bank Data).
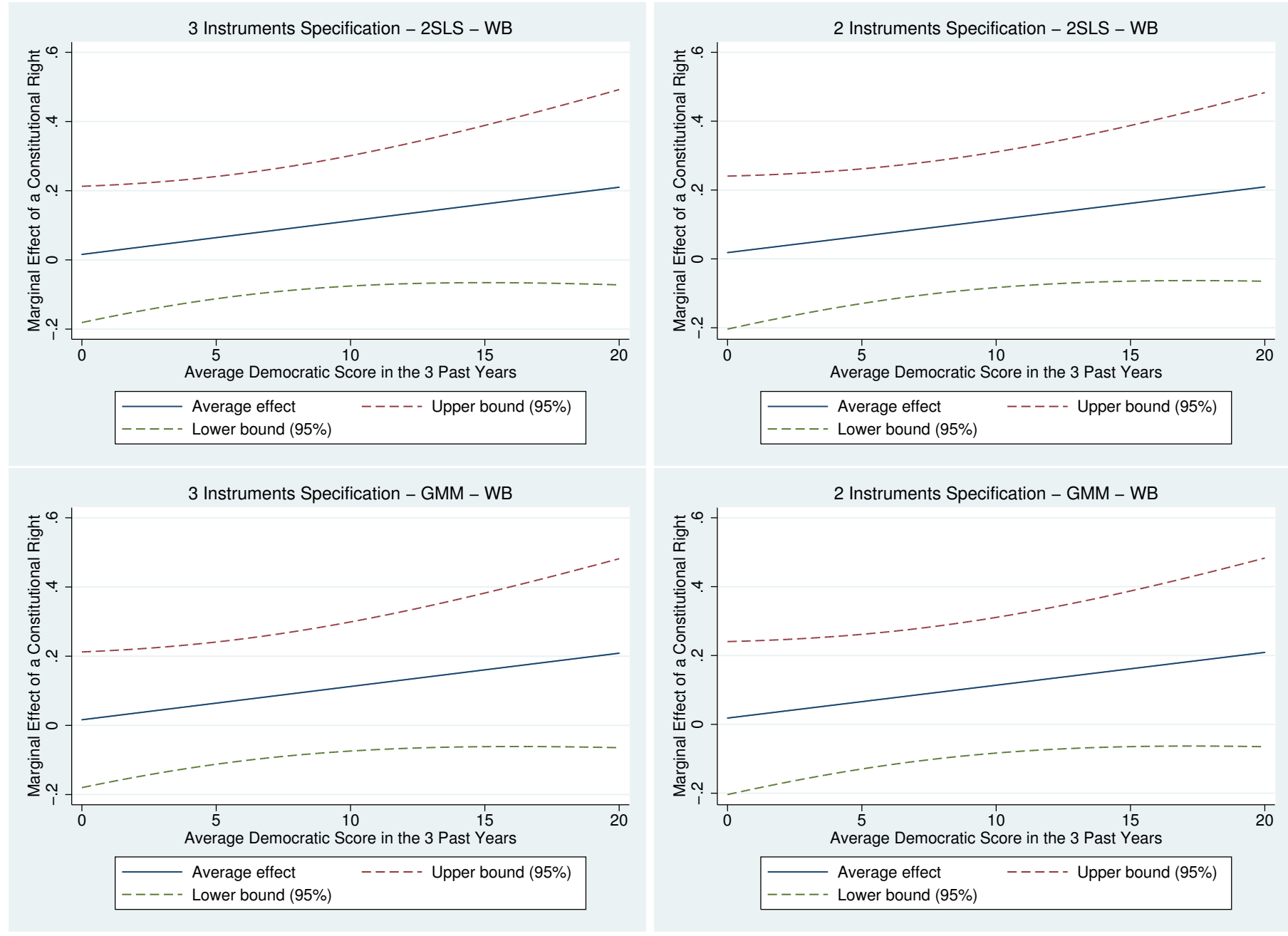


\section{B Tables}

\begin{tabular}{|c|c|c|c|}
\hline Variable & $\%$ in 1960 & $\%$ in 2012 & Evolution \\
\hline ARMS: The right to bear arms & .058 & .017 & -.041 \\
\hline ASSEM: Freedom of assembly & .756 & .928 & .172 \\
\hline ASSOC: Freedom of association & .733 & .922 & .189 \\
\hline ASYLUM: Provisions for the protection of stateless persons & .326 & .45 & .124 \\
\hline BUSINES: The right to conduct/establish a business & .14 & .378 & .238 \\
\hline CAPPUN: Restrictions on the use of capital punishment & .198 & .328 & .13 \\
\hline CENSOR: Prohibition of censorship & .256 & .311 & .055 \\
\hline CHILDPRO: Guarantee of the rights of children & .209 & .406 & .197 \\
\hline CHILDWRK: Limits on child employment & .221 & .322 & .101 \\
\hline CITDEP: Grant to the government of the right to deport citizens & .291 & .572 & .281 \\
\hline CITREN: The right of citizens to renounce their citizenship & .047 & .261 & .214 \\
\hline CITSUFF_1: Jus soli citizenship & .306 & .331 & .025 \\
\hline $\begin{array}{l}\text { CONRIGHT: Mention of consumer rights or consumer protection } \\
\text { protection }\end{array}$ & .047 & .233 & .186 \\
\hline CORPPUN: Prohibition on the use of corporal punishment & .047 & .033 & -.014 \\
\hline COUNS: The right to counsel if one is indicted & .291 & .728 & .437 \\
\hline CRUELTY: Prohibition of cruel, inhuman, or degrading treatment & .291 & .778 & .487 \\
\hline $\begin{array}{l}\text { CULTRGHT: Reference to a state duty to protect or promote cul- } \\
\text { ture }\end{array}$ & .314 & .617 & .303 \\
\hline DEBTORS: Prohibition on the detention of debtors & .163 & .139 & -.024 \\
\hline $\begin{array}{l}\text { DEVLPERS: Provision for an individual's right to self develop- } \\
\text { ment }\end{array}$ & .047 & .15 & .103 \\
\hline DOUBJEP: Prohibition of double jeopardy & .209 & .511 & .302 \\
\hline EXAMWIT: The right to examine evidence or confront all & .116 & .317 & .201 \\
\hline EXPOST: Prohibition of punishment by laws enacted ex post & .477 & .8 & .323 \\
\hline EXPRESS: Freedom of expression or speech & .756 & .939 & .183 \\
\hline FAIRTRI: The right to a fair trial & .128 & .5 & .372 \\
\hline $\begin{array}{l}\text { FALSEIMP: The right to some redress in cases of false imprison- } \\
\text { ment }\end{array}$ & .209 & .339 & .13 \\
\hline FNDFAM: The right to found a family & .163 & .306 & .143 \\
\hline FREECOMP: The right to a free and/or competitive market & .093 & .211 & .118 \\
\hline FREEMOVE: Freedom of movement & .465 & .85 & .385 \\
\hline FREEREL: Freedom of religion & .849 & .922 & .073 \\
\hline HABCORP: The right to protection from unjustified restraint & .651 & .761 & .11 \\
\hline $\begin{array}{l}\text { HEALTHF: Specification that healthcare should be provided at } \\
\text { state expense }\end{array}$ & .145 & .238 & .093 \\
\hline HEALTHR: Mention of the right to health care & .221 & .489 & .268 \\
\hline INFOACC: Right of an individual to view government information & .081 & .317 & .236 \\
\hline INHERIT: Inheritance rights & .209 & .294 & .085 \\
\hline INTPROP: Intellectual property rights & .25 & .231 & -.019 \\
\hline JOINTRDE: The right to form or to join trade unions & .477 & .739 & .262 \\
\hline $\begin{array}{l}\text { JURY: Requirement of a jury or any form of citizen participation } \\
\text { in criminal trials }\end{array}$ & .267 & .172 & -.095 \\
\hline $\begin{array}{l}\text { JUVENILE: Provision for juveniles of special rights/status in crim- } \\
\text { inal process }\end{array}$ & .035 & .139 & .104 \\
\hline LEISURE: A right of rest and leisure & .349 & .4 & .051 \\
\hline
\end{tabular}




\begin{tabular}{|c|c|c|c|}
\hline Variable & $\%$ in 1960 & $\%$ in 2012 & Evolution \\
\hline LIBEL: The right of protection of one's reputation & .163 & .289 & .126 \\
\hline LIFE: A right to life & .384 & .75 & .366 \\
\hline MARRIAGE: The right to marry & .105 & .089 & -.016 \\
\hline MATEQUAL: Provision for matrimonial equality & .174 & .322 & .148 \\
\hline $\begin{array}{l}\text { MIRANDA: A right of the accused to silence or protection from } \\
\text { self-incrimination }\end{array}$ & .256 & .517 & .261 \\
\hline $\begin{array}{l}\text { NOMIL: A right to exemption from military service for conscien- } \\
\text { tious objectors }\end{array}$ & .07 & .2 & .13 \\
\hline OCCUPATE: The right to choose one's occupation & .337 & .55 & .213 \\
\hline OPINION: Freedom of opinion, thought, and conscience & .512 & .806 & .294 \\
\hline PETITION: A right of petition & .616 & .55 & -.066 \\
\hline PREREL: The right/possibility of pretrial release & .221 & .294 & .073 \\
\hline PRESINOC: A presumption of innocence in trials & .233 & .733 & .5 \\
\hline PRESS: Freedom of the press & .535 & .633 & .098 \\
\hline $\begin{array}{l}\text { PRISONRG: Requirement that the names of those imprisoned be } \\
\text { recorded in a register }\end{array}$ & .023 & .022 & -.001 \\
\hline PRIVACY: A right of privacy & .64 & .839 & .199 \\
\hline PROPRGHT: A right to own property & .593 & .844 & .251 \\
\hline PROVHLTH: Mention of a state duty to provide health care & .256 & .428 & .172 \\
\hline $\begin{array}{l}\text { PROVWORK: Mention of a state duty to provide work employ- } \\
\text { ment }\end{array}$ & .186 & .128 & -.058 \\
\hline PUBTRI: A general requirement of public trials & .453 & .656 & .203 \\
\hline $\begin{array}{l}\text { REMUNER: The right to just remuneration, fair compensation, } \\
\text { etc. }\end{array}$ & .349 & .472 & .123 \\
\hline RGHTAPP: The right of defendants to appeal judicial decisions & .128 & .306 & .178 \\
\hline SAFEWORK: The right to safe/healthy working environment & .198 & .372 & .174 \\
\hline SAMESEXM: The right for same-sex marriages & 0 & 0 & 0 \\
\hline SCIFREE: A right to enjoy the benefits of science & .058 & .117 & .059 \\
\hline SELFDET: A people's right of self determination & .058 & .144 & .086 \\
\hline SEPREL: An explicit decree of separation of church and state & .279 & .261 & -.018 \\
\hline SHELTER: The right to shelter or housing & .093 & .267 & .174 \\
\hline SLAVE: Prohibition of slavery, servitude, or forced labor & .279 & .539 & .26 \\
\hline SPEEDTRI: The right to a speedy trial & .186 & .456 & .27 \\
\hline $\begin{array}{l}\text { STANDLIV: A right to an adequate or reasonable standard of } \\
\text { living }\end{array}$ & .186 & .211 & .025 \\
\hline STRIKE: A right to strike & .244 & .444 & .2 \\
\hline $\begin{array}{l}\text { TESTATE: A right of testacy, or the right to leave property to } \\
\text { one's heirs }\end{array}$ & .093 & .078 & -.015 \\
\hline TORTURE: Prohibition of torture & .326 & .739 & .413 \\
\hline TRANSFER: The right to transfer property freely & .163 & .167 & .004 \\
\hline $\begin{array}{l}\text { TRILANG: Specification that a trial has to be in a language of the } \\
\text { accused }\end{array}$ & .128 & .372 & .244 \\
\hline WOLAW: Mention of nulla poena sine lege or equivalent & .535 & 639 & .104 \\
\hline
\end{tabular}

Table 2: Percentage of constitutions including each right in 1960 and 2012, and the evolution between 1960 and 2012. 
Table 3: Descriptive Statistics

\begin{tabular}{lccccc}
\hline \hline & \multicolumn{3}{c}{$C_{i}$} \\
\cline { 2 - 3 } \cline { 5 - 6 } & \multicolumn{2}{c}{ PWT } & & World Bank \\
\cline { 2 - 3 } \cline { 5 - 6 } & Mean & $\begin{array}{c}\text { Standard } \\
\text { Deviation }\end{array}$ & & Mean & $\begin{array}{c}\text { Standard } \\
\text { Deviation }\end{array}$ \\
\hline SIZE & 14.715 & 5.84 & & 14.622 & 5.477 \\
RIGHTS & 25.807 & 13.373 & & 26.293 & 13.664 \\
DUR & 19.036 & 24.076 & & 19.473 & 24.831 \\
LOPOL & 23.11 & 8.269 & & 23.503 & 8.334 \\
ICCPR & .586 & .493 & & .606 & .489 \\
LGDP & 8.118 & 1.092 & & 8.16 & 1.1 \\
LPOP & 2.338 & 1.459 & & 2.38 & 1.472 \\
OPEN & .402 & .351 & & .417 & .341 \\
POL & 10.635 & 7.262 & & 11.37 & 7.117 \\
HC & 2.016 & .588 & & 2.039 & .593 \\
POP14 & 36.6 & 9.905 & & 36.203 & 10.036 \\
POP65 & 5.744 & 4.101 & & 5.871 & 4.22 \\
\hline \hline
\end{tabular}

The descriptive statistics correspond to the samples of the OLS estimations of tables 6 and 7 . 
Table 4: Constitutional Change since 1960: Probit Estimates

\begin{tabular}{|c|c|c|c|c|c|c|}
\hline & \multicolumn{6}{|c|}{$\mathrm{CH}_{i}$} \\
\hline & \multicolumn{2}{|c|}{ Average Values } & \multicolumn{2}{|c|}{ First Values } & \multicolumn{2}{|c|}{ Lastest Values } \\
\hline & PWT & WB & PWT & WB & PWT & WB \\
\hline & (1) & $(2)$ & $(3)$ & (4) & $(5)$ & (6) \\
\hline \multirow{2}{*}{$S I Z E$} & -0.0169 & -0.0183 & 0.011 & 0.0039 & -0.00088 & -0.0093 \\
\hline & $(-0.53)$ & $(-0.58)$ & $(0.42)$ & $(0.20)$ & $(-0.04)$ & $(-0.36)$ \\
\hline \multirow[t]{2}{*}{ RIGHTS } & -0.021 & -0.021 & $-0.029^{* *}$ & $-0.030^{* *}$ & 0.012 & 0.012 \\
\hline & $(-1.46)$ & $(-1.46)$ & $(-2.38)$ & $(-2.45)$ & $(0.91)$ & $(0.89)$ \\
\hline \multirow[t]{2}{*}{$D U R$} & -0.0047 & -0.0047 & 0.0024 & 0.0022 & -0.0067 & -0.0065 \\
\hline & $(-0.90)$ & $(-0.91)$ & $(0.53)$ & $(0.51)$ & $(-1.27)$ & $(-1.21)$ \\
\hline \multirow[t]{2}{*}{$I C C P R$} & -0.048 & -0.084 & . & • & 0.921 & 0.889 \\
\hline & $(-0.07)$ & $(-0.13)$ & 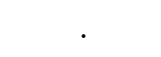 & & $(1.27)$ & $(1.23)$ \\
\hline \multirow[t]{2}{*}{$L G D P$} & -0.070 & -0.085 & -0.042 & -0.050 & 0.044 & 0.033 \\
\hline & $(-0.31)$ & $(-0.37)$ & $(-0.21)$ & $(-0.24)$ & $(0.18)$ & $(0.14)$ \\
\hline \multirow[t]{2}{*}{$\angle P O P$} & 0.070 & 0.067 & 0.051 & 0.050 & $0.199^{* *}$ & $0.191^{* *}$ \\
\hline & $(0.70)$ & $(0.68)$ & $(0.55)$ & $(0.53)$ & $(2.13)$ & (2.04) \\
\hline \multirow[t]{2}{*}{$O P E N$} & $-0.864^{*}$ & $-0.850^{*}$ & $-0.921^{*}$ & $-0.876^{*}$ & -0.219 & -0.215 \\
\hline & $(-1.72)$ & $(-1.72)$ & $(-1.80)$ & $(-1.73)$ & $(-1.54)$ & $(-1.61)$ \\
\hline \multirow[t]{2}{*}{$P O L$} & -0.015 & -0.013 & $-0.050^{* *}$ & $-0.051^{* *}$ & -0.010 & -0.0095 \\
\hline & $(-0.47)$ & $(-0.41)$ & $(-2.20)$ & $(-2.21)$ & $(-0.34)$ & $(-0.31)$ \\
\hline \multirow[t]{2}{*}{$H C$} & 0.599 & 0.605 & 0.350 & 0.385 & 0.433 & 0.446 \\
\hline & (1.12) & (1.14) & $(0.84)$ & $(0.91)$ & $(0.87)$ & $(0.90)$ \\
\hline \multirow[t]{2}{*}{ POP 14} & 0.053 & 0.050 & $0.096^{*}$ & $0.098^{*}$ & 0.023 & 0.022 \\
\hline & $(0.89)$ & $(0.84)$ & (1.93) & $(1.95)$ & $(0.64)$ & $(0.64)$ \\
\hline \multirow[t]{2}{*}{ POP65 } & 0.063 & 0.060 & 0.163 & 0.170 & -0.027 & -0.023 \\
\hline & $(0.56)$ & $(0.53)$ & $(1.17)$ & $(1.21)$ & $(-0.51)$ & $(-0.44)$ \\
\hline \# obs. & 114 & 113 & 114 & 113 & 114 & 113 \\
\hline Pseudo $\mathrm{R}^{2}$ & 0.125 & 0.123 & 0.186 & 0.183 & 0.142 & 0.140 \\
\hline Log Likelihood & -63.475 & -63.293 & -59.080 & -58.953 & -62.261 & -62.053 \\
\hline
\end{tabular}

$\mathrm{Z}$-values in parentheses. Robust standard errors. ICCPR is not included in the second specification, since no country ratified the ICCPR in 1960.

* Significant at the 10-percent level.

** Significant at the 5-percent level.

*** Significant at the 1-percent level. 
Table 5: Number of Rights: OLS and Heckman estimates

\begin{tabular}{|c|c|c|c|c|c|}
\hline Technique & OLS & OLS & OLS & \multicolumn{2}{|c|}{ Heckman } \\
\hline Dependent variable & $\begin{array}{c}\text { RIGHTS } \\
\text { (1) }\end{array}$ & $\begin{array}{c}\text { RIGHTS } \\
(2)\end{array}$ & $\begin{array}{c}\text { RIGHTS } \\
\text { (3) }\end{array}$ & $\begin{array}{c}\text { RIGHTS } \\
\text { (4) }\end{array}$ & $\begin{array}{c}C H \\
(5)\end{array}$ \\
\hline$S I Z E_{t-1}$ & $\begin{array}{c}-0.362^{* * *} \\
(-12.45)\end{array}$ & $\begin{array}{c}-0.266^{* * *} \\
(-4.860)\end{array}$ & $\begin{array}{c}-0.397^{* * *} \\
(-3.189)\end{array}$ & $\begin{array}{c}-0.453^{* *} \\
(-2.435)\end{array}$ & $\begin{array}{l}-0.0104 \\
(-1.589)\end{array}$ \\
\hline$D U R_{t-1}$ & $\begin{array}{c}-0.111^{* * *} \\
(-16.37)\end{array}$ & $\begin{array}{c}-0.0715^{* * *} \\
(-5.728)\end{array}$ & $\begin{array}{c}-0.00622 \\
(-0.174)\end{array}$ & $\begin{array}{c}-0.00611 \\
(-0.147)\end{array}$ & $\begin{array}{c}-0.00165 \\
(-1.295)\end{array}$ \\
\hline$I C C P R_{t-1}$ & $\begin{array}{c}2.038^{* * *} \\
(4.016)\end{array}$ & $\begin{array}{c}2.545^{* * *} \\
(2.592)\end{array}$ & $\begin{array}{c}0.457 \\
(0.201)\end{array}$ & $\begin{array}{l}-0.0505 \\
(-0.0169)\end{array}$ & $\begin{array}{l}-0.0102 \\
(-0.101)\end{array}$ \\
\hline$L G D P_{t-1}$ & $\begin{array}{c}2.787^{* * *} \\
(8.987)\end{array}$ & $\begin{array}{c}5.576^{* * * *} \\
(8.811)\end{array}$ & $\begin{array}{c}4.846^{* * *} \\
(3.423)\end{array}$ & $\begin{array}{c}4.175^{* *} \\
(2.505)\end{array}$ & $\begin{array}{l}0.0252 \\
(0.447)\end{array}$ \\
\hline$L P O P_{t-1}$ & $\begin{array}{c}0.654^{* * *} * \\
(4.688)\end{array}$ & $\begin{array}{c}0.682^{* *} \\
(2.451)\end{array}$ & $\begin{array}{c}-0.978 \\
(-1.519)\end{array}$ & $\begin{array}{c}0.248 \\
(0.299)\end{array}$ & $\begin{array}{c}0.0740^{* * *} * \\
(2.766)\end{array}$ \\
\hline$O P E N_{t-1}$ & $\begin{array}{c}-2.065^{* * *} \\
(-3.713)\end{array}$ & $\begin{array}{c}-3.761^{* * *} \\
(-2.855)\end{array}$ & $\begin{array}{c}-8.244^{* *} \\
(-2.547)\end{array}$ & $\begin{array}{l}-5.863^{*} \\
(-1.799)\end{array}$ & $\begin{array}{c}0.157 \\
(1.441)\end{array}$ \\
\hline$P O L_{t-1}$ & $\begin{array}{c}0.494^{* * *} \\
(16.76)\end{array}$ & $\begin{array}{c}0.132^{* *} \\
(2.048)\end{array}$ & $\begin{array}{c}0.198 \\
(1.444)\end{array}$ & $\begin{array}{c}0.280 \\
(1.431)\end{array}$ & $\begin{array}{c}0.00739 \\
(1.136)\end{array}$ \\
\hline$P O P 14_{t-1}$ & $\begin{array}{l}0.0137 \\
(0.259)\end{array}$ & $\begin{array}{c}0.116 \\
(1.087)\end{array}$ & $\begin{array}{l}0.0451 \\
(0.154)\end{array}$ & $\begin{array}{c}-0.109 \\
(-0.333)\end{array}$ & $\begin{array}{c}-0.00502 \\
(-0.481)\end{array}$ \\
\hline$P O P 65_{t-1}$ & $\begin{array}{c}-0.529 * * * \\
(-4.120)\end{array}$ & $\begin{array}{c}-1.241^{* * *} \\
(-4.796)\end{array}$ & $\begin{array}{c}-0.965 \\
(-1.288)\end{array}$ & $\begin{array}{l}-1.297^{*} \\
(-1.779)\end{array}$ & $\begin{array}{l}-0.0171 \\
(-0.726)\end{array}$ \\
\hline$T R E N D_{t}$ & $\begin{array}{c}0.278 * * * \\
(14.73)\end{array}$ & $\begin{array}{c}0.422^{* * *} \\
(10.53)\end{array}$ & $\begin{array}{c}0.459^{* * *} \\
(5.019)\end{array}$ & $\begin{array}{c}0.377^{* * *} \\
(3.218)\end{array}$ & $\begin{array}{c}-0.00439 \\
(-1.198)\end{array}$ \\
\hline$P R E S S_{t-1}$ & & & & & $\begin{array}{c}0.0127^{* * *} \\
(4.90)\end{array}$ \\
\hline \# obs. & 3,564 & 904 & 177 & \multicolumn{2}{|c|}{3,511} \\
\hline Pseudo $\mathrm{R}^{2}$ & 0.337 & 0.362 & 0.352 & & \\
\hline Log Likelihood & & & & \multicolumn{2}{|c|}{-1370.671} \\
\hline Lambda & & & & 20.949 & (3.383) \\
\hline Rho & & & & 0.928 & $(0.0310)$ \\
\hline LR $\rho=0$ (p-value $)$ & & & & \multicolumn{2}{|c|}{0.000} \\
\hline
\end{tabular}

Z-values in parentheses, except for Lambda and Rho (standard errors). Robust standard errors. $H C$ is not included because convergence of the Heckman estimation was not obtained when included. OLS estimates were similar when included.

* Significant at the 10-percent level.

** Significant at the 5-percent level.

*** Significant at the 1-percent level. 
Table 6: Estimation of the impact of the number of constitutional rights on the Government Size (Penn World Table Data).

\begin{tabular}{|c|c|c|c|c|c|}
\hline Specification & $(1)$ & $(2)$ & (3) & (4) & $(5)$ \\
\hline PWT data & OLS & IV & IV & IV & IV \\
\hline RIGHTS & $\begin{array}{c}-0.00902 \\
(0.727)\end{array}$ & & & & \\
\hline RIGHTS (GMM) & & $\begin{array}{r}-0.0767 \\
(0.524)\end{array}$ & $\begin{array}{c}-0.0613 \\
(0.620)\end{array}$ & $\begin{array}{c}0.149 \\
(0.444)\end{array}$ & $\begin{array}{l}-0.118 \\
(0.440)\end{array}$ \\
\hline RIGHTS (2SLS) & & $\begin{array}{c}-0.0223 \\
(0.872)\end{array}$ & $\begin{array}{c}-0.0943 \\
(0.456)\end{array}$ & $\begin{array}{c}0.286 \\
(0.225)\end{array}$ & $\begin{array}{c}-0.00498 \\
(0.976)\end{array}$ \\
\hline Observations & & & & & \\
\hline Number of countries & 73 & 73 & 73 & 73 & 73 \\
\hline Country FE & Yes & Yes & Yes & Yes & Yes \\
\hline Year FE & Yes & Yes & Yes & Yes & Yes \\
\hline$C H_{-} W A R$ & . & Yes & No & Yes & Yes \\
\hline $\mathrm{CH}_{-}^{-} \mathrm{LOPOL}$ & . & Yes & Yes & Yes & No \\
\hline$D R \bar{A} F T E R$ & . & Yes & Yes & No & Yes \\
\hline Underident. Test p-value & . & Reject $(1 \%)$ & Reject $(1 \%)$ & Reject $(1 \%)$ & Reject $(1 \%)$ \\
\hline Overident. test p-value & . & 0.202 & 0.216 & 0.304 & 0.0835 \\
\hline Endogeneity Test & . & Don't Reject & Don't Reject & Don't Reject & Don't Reject \\
\hline Weak Ident. F-Test & . & 10.36 & 15.37 & 4.932 & 14.92 \\
\hline Stock-Yogo $10 \%$ & . & 22.30 & 19.93 & 19.93 & 19.93 \\
\hline Stock-Yogo $15 \%$ & . & 12.83 & 11.59 & 11.59 & 11.59 \\
\hline Stock-Yogo $20 \%$ & . & 9.54 & 8.75 & 8.75 & 8.75 \\
\hline Stock-Yogo $25 \%$ & . & 7.80 & 7.25 & 7.25 & 7.25 \\
\hline
\end{tabular}

Within estimation of SIZE. Robust and clustered standard errors. P-values in parentheses. Control variables include: LGDP, LPOP, OPEN, HC, POP14, POP65, POL, ICCPR, DUR, LOPOL.

* Significant at the 10-percent level.

** Significant at the 5-percent level.

*** Significant at the 1-percent level. 
Table 7: Estimation of the impact of the number of constitutional rights on the Government Size (World Bank Data).

\begin{tabular}{|c|c|c|c|c|c|}
\hline Specification & $(1)$ & $(2)$ & $(3)$ & (4) & $(5)$ \\
\hline World Bank data & OLS & IV & IV & IV & IV \\
\hline RIGHTS & $\begin{array}{c}-0.000363 \\
(0.989)\end{array}$ & & & & \\
\hline RIGHTS (GMM) & & $\begin{array}{l}0.0665 \\
(0.490)\end{array}$ & $\begin{array}{l}0.0864 \\
(0.376)\end{array}$ & $\begin{array}{l}0.0196 \\
(0.872)\end{array}$ & $\begin{array}{l}0.0798 \\
(0.504)\end{array}$ \\
\hline RIGHTS (2SLS) & & $\begin{array}{l}0.0991 \\
(0.358)\end{array}$ & $\begin{array}{l}0.0782 \\
(0.439)\end{array}$ & $\begin{array}{c}0.120 \\
(0.402)\end{array}$ & $\begin{array}{c}0.113 \\
(0.372)\end{array}$ \\
\hline Observations & 1,986 & 1,651 & 1,654 & 1,851 & 1,651 \\
\hline Number of countries & 72 & 68 & 68 & 68 & 68 \\
\hline Country FE & Yes & Yes & Yes & Yes & Yes \\
\hline Year FE & Yes & Yes & Yes & Yes & Yes \\
\hline$C H_{-} W A R$ & . & Yes & No & Yes & Yes \\
\hline $\mathrm{CH}_{-} \mathrm{LOPOL}$ & . & Yes & Yes & Yes & No \\
\hline$D R \bar{A} F T E R$ & . & Yes & Yes & No & Yes \\
\hline Underident. Test p-value & . & Reject (1\%) & Reject (1\%) & Reject $(1 \%)$ & Reject $(1 \%)$ \\
\hline Overident. test p-value & . & 0.710 & 0.749 & 0.189 & 0.426 \\
\hline Endogeneity Test & . & Don't Reject & Don't Reject & Don't Reject & Don't Reject \\
\hline Weak Ident. F-Test & . & 9.451 & 14.04 & 5.118 & 12.66 \\
\hline Stock-Yogo $10 \%$ & . & 22.30 & 19.93 & 19.93 & 19.93 \\
\hline Stock-Yogo 15\% & . & 12.83 & 11.59 & 11.59 & 11.59 \\
\hline Stock-Yogo $20 \%$ & . & 9.54 & 8.75 & 8.75 & 8.75 \\
\hline Stock-Yogo $25 \%$ & . & 7.80 & 7.25 & 7.25 & 7.25 \\
\hline
\end{tabular}

Within estimation of SIZE. Robust and clustered standard errors. P-values in parentheses. Control variables include: LGDP, LPOP, OPEN, HC, POP14, POP65, POL, ICCPR, DUR, LOPOL.

* Significant at the 10-percent level.

** Significant at the 5-percent level.

*** Significant at the 1-percent level. 
Table 8: First Stage Estimates of table 6.

\begin{tabular}{lcccc}
\hline \hline Specification & $(2)$ & $(3)$ & $(4)$ & $(5)$ \\
\hline CH_WAR & 0.0672 & & 0.0807 & .01073 \\
& $(0.470)$ &. & $(0.265)$ & $(0.177)$ \\
CH_LOPOL & 0.2027 & $0.2388^{* *}$ & $0.2044^{*}$ & \\
& $(0.129)$ & $(0.025)$ & $(0.083)$ &. \\
DRAFTER & $6.170^{* * *}$ & $5.982^{* * *}$ & & $6.187^{* * *}$ \\
& $(0.000)$ & $(0.000)$ &. & $(0.000)$ \\
& & & & \\
Partial-R & & & & \\
\hline \hline
\end{tabular}

First stage estimates of the IV within estimation of SIZE. Robust and clustered standard errors. P-values in parentheses. Control variables include: LGDP, LPOP, OPEN, HC, POP14, POP65, POL, ICCPR, DUR, LOPOL.

* Significant at the 10-percent level.

** Significant at the 5-percent level.

$* * *$ Significant at the 1-percent level.

Table 9: First Stage Estimates of table 7.

\begin{tabular}{|c|c|c|c|c|}
\hline Specification & (2) & (3) & (4) & (5) \\
\hline \multirow{2}{*}{$\mathrm{CH}_{\text {_WAR }}$} & 0.0816 & & 0.0959 & 0.1246 \\
\hline & $(0.433)$ & & $(0.231)$ & $(0.193)$ \\
\hline \multirow[t]{2}{*}{$\mathrm{CH}_{-} \mathrm{LOPOL}$} & $0.2782^{*}$ & $0.3055^{* *}$ & $0.3176^{* *}$ & \\
\hline & $(0.083)$ & $(0.028)$ & $(0.038)$ & 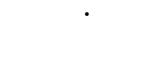 \\
\hline DRAFTER & $\begin{array}{c}6.564^{* * *} \\
(0.000)\end{array}$ & $\begin{array}{c}6.346^{* * *} \\
(0.000)\end{array}$ & & $\begin{array}{c}6.687^{* * *} \\
(0.000)\end{array}$ \\
\hline Partial- $\mathrm{R}^{2}$ & 0.1038 & 0.0937 & 0.0397 & 0.0856 \\
\hline
\end{tabular}

First stage estimates of the IV within estimation of SIZE. Robust and clustered standard errors. P-values in parentheses. Control variables include: LGDP, LPOP, OPEN, HC, POP14, POP65, POL, ICCPR, DUR, LOPOL.

* Significant at the 10-percent level.

** Significant at the 5-percent level.

*** Significant at the 1-percent level. 
Table 10: Estimation of the impact of the number of constitutional rights on the Government Size (Penn World Table Data).

\begin{tabular}{|c|c|c|c|c|c|c|c|}
\hline $\begin{array}{l}\text { Specification } \\
\text { PWT data }\end{array}$ & $\begin{array}{l}(1) \\
\text { OLS }\end{array}$ & $\begin{array}{l}\text { (2) } \\
\text { IV }\end{array}$ & $\begin{array}{l}\text { (3) } \\
\text { IV }\end{array}$ & (4) & (5) & (6) & (7) \\
\hline RIGHTS & $\begin{array}{r}-0.0547 \\
(0.168)\end{array}$ & & & & & & \\
\hline$I N T \_R I G H T S$ & $\begin{array}{c}0.00482 \\
(0.109)\end{array}$ & & & & & & \\
\hline RIGHTS (GMM) & & $\begin{array}{c}-0.228^{* *} \\
(0.0305)\end{array}$ & $\begin{array}{l}-0.164 \\
(0.142)\end{array}$ & $\begin{array}{c}0.177 \\
(0.446)\end{array}$ & $\begin{array}{l}-0.187 \\
(0.189)\end{array}$ & $\begin{array}{l}-0.130 \\
(0.317)\end{array}$ & $\begin{array}{l}-0.217 \\
(0.115)\end{array}$ \\
\hline$I N T \_R I G H T S$ & & $\begin{array}{c}0.00529 \\
(0.378)\end{array}$ & $\begin{array}{c}0.00695 \\
(0.265)\end{array}$ & $\begin{array}{c}-0.00194 \\
(0.841)\end{array}$ & $\begin{array}{c}0.0181^{*} \\
(0.0767)\end{array}$ & $\begin{array}{c}0.00556 \\
(0.404)\end{array}$ & $\begin{array}{c}0.00889 \\
(0.187)\end{array}$ \\
\hline RIGHTS (2SLS) & & $\begin{array}{c}-0.0903 \\
(0.519)\end{array}$ & $\begin{array}{l}-0.174 \\
(0.123)\end{array}$ & $\begin{array}{c}0.256 \\
(0.414)\end{array}$ & $\begin{array}{c}-0.0549 \\
(0.734)\end{array}$ & $\begin{array}{l}-0.143 \\
(0.274)\end{array}$ & $\begin{array}{l}-0.217 \\
(0.115)\end{array}$ \\
\hline$I N T \_R I G H T S$ & & $\begin{array}{c}0.00448 \\
(0.512)\end{array}$ & $\begin{array}{c}0.00581 \\
(0.396)\end{array}$ & $\begin{array}{c}-0.00299 \\
(0.775)\end{array}$ & $\begin{array}{c}0.00818 \\
(0.486)\end{array}$ & $\begin{array}{c}0.00342 \\
(0.618)\end{array}$ & $\begin{array}{c}0.00889 \\
(0.187)\end{array}$ \\
\hline Observations & 2,152 & 1,889 & 1,892 & 2,149 & 1,889 & 1,892 & 1,892 \\
\hline \# countries & 73 & 72 & 72 & 72 & 72 & 72 & 72 \\
\hline Country FE & Yes & Yes & Yes & Yes & Yes & Yes & Yes \\
\hline Year FE & Yes & Yes & Yes & Yes & Yes & Yes & Yes \\
\hline$C H \_W A R$ & . & Yes & Yes & Yes & No & No & No \\
\hline inter_CH_WAR & & Yes & Yes & Yes & No & No & No \\
\hline$C H \_L O P O L$ & . & Yes & Yes & No & Yes & Yes & No \\
\hline inter_CH_LOPOL & & Yes & Yes & No & Yes & Yes & Yes \\
\hline$D R A F T E R$ & . & Yes & No & Yes & Yes & Yes & Yes \\
\hline inter_DRAFTER & & Yes & No & Yes & Yes & No & No \\
\hline Underidentification & . & Reject (1\%) & Reject (1\%) & Reject (5\%) & Reject (5\%) & Reject (1\%) & Reject $(1 \%)$ \\
\hline Overidentification & . & 0.230 & 0.364 & 0.395 & 0.228 & 0.182 & . \\
\hline Weak Ident. F-Test & . & 3.972 & 6.030 & 2.447 & 2.254 & 8.019 & 11.60 \\
\hline Stock-Yogo 10\% & . & 21.68 & 16.87 & 16.87 & 16.87 & 13.43 & 7.03 \\
\hline Stock-Yogo 15\% & . & 12.33 & 9.93 & 9.93 & 9.93 & 8.18 & 4.58 \\
\hline Stock-Yogo $20 \%$ & . & 9.10 & 7.54 & 7.54 & 7.54 & 6.40 & 3.95 \\
\hline Stock-Yogo 25\% & . & 7.42 & 6.28 & 6.28 & 6.28 & 5.45 & 3.63 \\
\hline
\end{tabular}

Within estimation of SIZE. Robust and clustered standard errors. P-values in parentheses. Control variables include: LGDP, LPOP, OPEN, HC, POP14, POP65, POL, ICCPR, DUR, LOPOL.

* Significant at the 10-percent level.

** Significant at the 5-percent level.

*** Significant at the 1-percent level. 
Table 11: Estimation of the impact of the number of constitutional rights on the Government Size (World Bank Data).

\begin{tabular}{|c|c|c|c|c|c|c|c|}
\hline Specification & $\begin{array}{l}(1) \\
\text { OLS }\end{array}$ & $\begin{array}{l}(2) \\
\text { IV }\end{array}$ & $\begin{array}{l}\text { (3) } \\
\text { IV }\end{array}$ & $\begin{array}{l}\text { (4) } \\
\text { IV }\end{array}$ & $\begin{array}{l}(5) \\
\text { IV }\end{array}$ & $\begin{array}{l}\text { (6) } \\
\text { IV }\end{array}$ & $\begin{array}{l}\text { (7) } \\
\text { IV }\end{array}$ \\
\hline RIGHTS & $\begin{array}{c}-0.0890^{* *} \\
(0.0427)\end{array}$ & & & & & & \\
\hline$I N T \_R I G H T S$ & $\begin{array}{c}0.00893^{* *} \\
(0.0139)\end{array}$ & & & & & & \\
\hline RIGHTS (GMM) & & . & $\begin{array}{c}-0.0285 \\
(0.744)\end{array}$ & $\begin{array}{l}-0.125 \\
(0.455)\end{array}$ & $\begin{array}{r}-0.0126 \\
(0.897)\end{array}$ & $\begin{array}{l}0.0162 \\
(0.871)\end{array}$ & $\begin{array}{l}0.0183 \\
(0.872)\end{array}$ \\
\hline$I N T T_{-} R I G H S$ & & . & $\begin{array}{c}0.0143^{* *} \\
(0.0199)\end{array}$ & $\begin{array}{l}0.0187^{*} \\
(0.0848)\end{array}$ & $\begin{array}{c}0.0213^{* *} \\
(0.0268)\end{array}$ & $\begin{array}{c}0.00962 \\
(0.201)\end{array}$ & $\begin{array}{c}0.00954 \\
(0.222)\end{array}$ \\
\hline RIGHTS (2SLS) & & $\begin{array}{c}0.00567 \\
(0.960)\end{array}$ & $\begin{array}{c}-0.0444 \\
(0.616)\end{array}$ & $\begin{array}{l}0.0566 \\
(0.784)\end{array}$ & $\begin{array}{l}0.0219 \\
(0.847)\end{array}$ & $\begin{array}{l}0.0158 \\
(0.875)\end{array}$ & $\begin{array}{l}0.0183 \\
(0.872)\end{array}$ \\
\hline$I N T \_R I G H T S$ & & $\begin{array}{l}0.0132 * \\
(0.0562)\end{array}$ & $\begin{array}{l}0.0128^{*} \\
(0.0557)\end{array}$ & $\begin{array}{c}0.0142 \\
(0.209)\end{array}$ & $\begin{array}{l}0.0133 \\
(0.255)\end{array}$ & $\begin{array}{c}0.00971 \\
(0.216)\end{array}$ & $\begin{array}{c}0.00954 \\
(0.222)\end{array}$ \\
\hline Observations & 2,152 & 1,889 & 1,892 & 2,149 & 1,889 & 1,892 & 1,892 \\
\hline \# countries & 73 & 72 & 72 & 72 & 72 & 72 & 72 \\
\hline Country FE & Yes & Yes & Yes & Yes & Yes & Yes & Yes \\
\hline Year FE & Yes & Yes & Yes & Yes & Yes & Yes & Yes \\
\hline $\mathrm{CH}_{-} W A R$ & . & Yes & Yes & Yes & No & No & No \\
\hline inter_CH_WAR & & Yes & Yes & Yes & No & No & No \\
\hline $\mathrm{CH}_{-} \mathrm{LOPOL}$ & . & Yes & Yes & No & Yes & Yes & No \\
\hline inter_CH_LOPOL & & Yes & Yes & No & Yes & Yes & Yes \\
\hline$D R A F T E R$ & . & Yes & No & Yes & Yes & Yes & Yes \\
\hline inter_DRAFTER & & Yes & No & Yes & Yes & No & No \\
\hline Underidentification & . & Reject (5\%) & Reject $(1 \%)$ & Reject (5\%) & Reject $(10 \%)$ & Reject $(1 \%)$ & Reject $(1 \%)$ \\
\hline Overidentification & . & . & 0.504 & 0.265 & 0.403 & 0.968 & . \\
\hline Weak Ident. F-Test & . & 3.270 & 4.938 & 2.662 & 2.067 & 6.712 & 13.13 \\
\hline Stock-Yogo 10\% & . & 21.68 & 16.87 & 16.87 & 16.87 & 13.43 & 7.03 \\
\hline Stock-Yogo $15 \%$ & . & 12.33 & 9.93 & 9.93 & 9.93 & 8.18 & 4.58 \\
\hline Stock-Yogo 20\% & . & 9.10 & 7.54 & 7.54 & 7.54 & 6.40 & 3.95 \\
\hline Stock-Yogo $25 \%$ & . & 7.42 & 6.28 & 6.28 & 6.28 & 5.45 & 3.63 \\
\hline
\end{tabular}

Within estimation of SIZE. Robust and clustered standard errors. P-values in parentheses. Control variables include: LGDP, LPOP, OPEN, HC, POP14, POP65, POL, ICCPR, DUR, LOPOL.

* Significant at the 10-percent level.

** Significant at the 5-percent level.

*** Significant at the 1-percent level. 
Table 12: Robustness Check: Estimation of the impact of the number of constitutional rights on the Government Size (Penn World Table Data).

\begin{tabular}{|c|c|c|c|c|c|}
\hline Specification & $\overline{~(1)}$ & 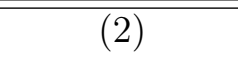 & (3) & $\overline{(4)}$ & $(5)$ \\
\hline PWT data & OLS & IV & IV & IV & IV \\
\hline$S U B \_R I G H T S$ & $\begin{array}{c}0.151 \\
(0.200)\end{array}$ & & & & \\
\hline$S U B \_R I G H T S(\mathrm{GMM})$ & & $\begin{array}{l}-0.291 \\
(0.398)\end{array}$ & $\begin{array}{l}-0.205 \\
(0.572)\end{array}$ & $\begin{array}{c}0.299 \\
(0.504)\end{array}$ & $\begin{array}{c}-0.439 \\
(0.322)\end{array}$ \\
\hline$S U B \_R I G H T S$ (2SLS) & & $\begin{array}{l}-0.139 \\
(0.723)\end{array}$ & $\begin{array}{l}-0.267 \\
(0.467)\end{array}$ & $\begin{array}{c}0.698 \\
(0.199)\end{array}$ & $\begin{array}{c}-0.0964 \\
(0.844)\end{array}$ \\
\hline Observations & 2,089 & 1,853 & 1,856 & 2,086 & 1,853 \\
\hline Number of countries & 69 & 68 & 68 & 69 & 68 \\
\hline Country FE & Yes & Yes & Yes & Yes & Yes \\
\hline Year FE & Yes & Yes & Yes & Yes & Yes \\
\hline$C H_{-} W A R$ & . & Yes & No & Yes & Yes \\
\hline $\mathrm{CH}_{-}^{-} \mathrm{LOPOL}$ & . & Yes & Yes & Yes & No \\
\hline$D R \bar{A} F T E R$ & . & Yes & Yes & No & Yes \\
\hline Underident. Test p-value & . & Reject $(1 \%)$ & Reject $(1 \%)$ & Reject $(1 \%)$ & Reject $(1 \%)$ \\
\hline Weak Ident. F-Test & . & 11.67 & 17.20 & 6.430 & 15.27 \\
\hline Stock-Yogo $10 \%$ & . & 22.30 & 19.93 & 19.93 & 19.93 \\
\hline Stock-Yogo 15\% & . & 12.83 & 11.59 & 11.59 & 11.59 \\
\hline Stock-Yogo $20 \%$ & . & 9.54 & 8.75 & 8.75 & 8.75 \\
\hline Stock-Yogo 25\% & . & 7.80 & 7.25 & 7.25 & 7.25 \\
\hline Overident. test p-value & . & 0.219 & 0.201 & 0.196 & 0.0970 \\
\hline Endogeneity Test & . & Don't Reject & Don't Reject & Don't Reject & Don't Reject \\
\hline
\end{tabular}

Within estimation of SIZE. Robust and clustered standard errors. P-values in parentheses. Control variables include: LGDP, LPOP, OPEN, HC, POP14, POP65, POL, ICCPR, DUR, LOPOL.

* Significant at the 10-percent level.

** Significant at the 5-percent level.

*** Significant at the 1-percent level. 
Table 13: Robustness Check: Estimation of the impact of the number of constitutional rights on the Government Size (World Bank Data).

\begin{tabular}{|c|c|c|c|c|c|}
\hline Specification & $\overline{7(1)}$ & (2) & (3) & (4) & $(5)$ \\
\hline World Bank data & OLS & IV & IV & IV & IV \\
\hline$S U B \_R I G H T S$ & $\begin{array}{c}0.207^{*} \\
(0.0728)\end{array}$ & & & & \\
\hline$S U B \_R I G H T S(\mathrm{GMM})$ & & . & $\begin{array}{c}0.333 \\
(0.269)\end{array}$ & $\begin{array}{c}0.292 \\
(0.467)\end{array}$ & $\begin{array}{c}0.213 \\
(0.552)\end{array}$ \\
\hline$S U B \_R I G H T S$ (2SLS) & & $\begin{array}{c}0.308 \\
(0.342)\end{array}$ & $\begin{array}{c}0.259 \\
(0.407)\end{array}$ & $\begin{array}{c}0.648 \\
(0.177)\end{array}$ & $\begin{array}{c}0.281 \\
(0.442)\end{array}$ \\
\hline Observations & 1,889 & 1,586 & 1,589 & 1,736 & 1,586 \\
\hline Number of countries & 68 & 63 & 63 & 63 & 63 \\
\hline Country FE & Yes & Yes & Yes & Yes & Yes \\
\hline Year FE & Yes & Yes & Yes & Yes & Yes \\
\hline$C H \_W A R$ & . & Yes & No & Yes & Yes \\
\hline $\mathrm{CH}_{-}^{-} \mathrm{LOPOL}$ & . & Yes & Yes & Yes & No \\
\hline$D R \bar{A} F T E R$ & . & Yes & Yes & No & Yes \\
\hline Underident. Test p-value & . & Reject $(1 \%)$ & Reject $(1 \%)$ & Reject $(1 \%)$ & Reject $(1 \%)$ \\
\hline Weak Ident. F-Test & . & 12.41 & 17.76 & 5.566 & 14.60 \\
\hline Stock-Yogo $10 \%$ & . & 22.30 & 19.93 & 19.93 & 19.93 \\
\hline Stock-Yogo $15 \%$ & . & 12.83 & 11.59 & 11.59 & 11.59 \\
\hline Stock-Yogo $20 \%$ & . & 9.54 & 8.75 & 8.75 & 8.75 \\
\hline Stock-Yogo 25\% & . & 7.80 & 7.25 & 7.25 & 7.25 \\
\hline Overident. test $\mathrm{p}$-value & . & . & 0.370 & 0.176 & 0.367 \\
\hline Endogeneity Test & . & Don't Reject & Don't Reject & Don't Reject & Don't Reject \\
\hline
\end{tabular}

Within estimation of SIZE. Robust and clustered standard errors. P-values in parentheses. Control variables include: LGDP, LPOP, OPEN, HC, POP14, POP65, POL, ICCPR, DUR, LOPOL.

* Significant at the 10-percent level.

** Significant at the 5-percent level.

*** Significant at the 1-percent level. 